\title{
A VEGETAÇÃO COMO \\ ELEMENTO DE PROJETO
}

SILVTO SOARES MACEDO

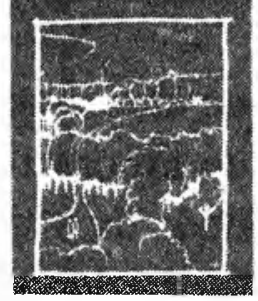

Os anos 80 se caracterizam por constituir parte de uma década na qual as questões do "verde" e da ecologia passaram a ser cada vez mais e mais socialmente aceitas, pois existe uma preocupação geral com a conservação, a preservação e a manutenção da vegetação, tanto a nível do urbano como no campo ou nas últimas fronteiras de colonização do planeta.

No meio de todas estas idéias uma série de "fetiches" e "tótens" tem sido lançada sobre a "entidade" vegetação è muitos vêem nas selvas, bosques e arvoredos a panacéia para a solução de todos os nossos problemas ambientais. $\mathrm{Na}$ realidade toda a estrutura vegetal da Terra é constituída de seres vivos, que como os humanos, nascem, crescem e morrem e necessitam de ambientes adequados para se desenvolverem e como eles sofrem as conseqüências da degradação ambiental causada pela poluição do ar, da água, pelos processos de exploração das matas e cerrados, enfim pela forma predatória de apropriação dos recursos naturais, vigente em grande parte da superfície terrestre.

Dentro do contexto urbano ocidental a vegetação é incorporada a seus espaços livres e da forma que conhecemos hoje, a partir do final do séc. XVIII, pois, com o crescimento das cidades européias e americanas (USA) o elemento vegetal passa a ter papel estrutural na conformação de seus espaços livres, em especial os parques e as praças.

Este por milênios desempenha um papel restrito nas cidades, concentrado que foi em quintais e jardins, parques de palácios e pátios de conventos e só esporadicamente constituíram parte estrutural dos espaços públicos, praças medievais, "foruns" das cidades romanas, "ágoras" gregas são praticamente desprovidos de vegetação e esta só adquire um papel de real importância nos primeiros parques abertos ao público na Inglaterra do séc. XVIII (como o Hyde Park) e anteriormente pertencentes à Coroa Real.

O séc. XIX é um período de profundas reformulações, de melhorias na cidade e portanto no desenho da paisagem urbana e nesta época os parques e praças, tal qual os conhecemos hoje, são então incorporados à linguagem da cidade. 
Cria-se toda uma escola de desenho dos espaços livres páblicos, que são densamente arborizados, muitas vezes cercados por gradis, possuindo fontes, esculturas e outros elementos decorativos. Os grandes espaços, sejam eles parques ou praças, possuem extensos gramados, sempre procurando-se uma construção cênica de caráter nitidamente romântico, onde a idéia de bucolismo é dominante.

Na segunda metade do século, na Paris reformada por Haussmann abrem-se os grandes "boulevards", avenidas de largas calçadas e densamente arborizadas, que servem como padrão às outras cidades. No Brasil, na cidade de São Paulo do fim do século, o mais novo bairro destinado às elites, o Higienópolis, tem como codinome "Boulevard Burchard", indicando o caráter de suas ruas todas largas e arborizadas "tal qual as de Paris" Na mesma época é aberta também na capital a avenida Paulista (1891), também toda arborizada. Por toda a cidade, a princípio nos bairros de elite e depois pelos subúrbios novos destinados às classes médias, a arborização surge como um padrão de urbanização. Do mesmo modo, no Rio de Janeiro, na segunda década do séc. XX é aberta a avenida Central, também calçada nos padrões dos boulevards parisienses e um marco referencial do urbanismo nacional.

Paralelamente, a introdução do plantio de árvores nas ruas se consolida em um novo modelo de assentamento da residência no lote, isolada em contraponto ao padrão colonial de prédios isolados entre si. Surgem dentro do contexto urbano brasileiro as figuras dos jardins, parques, praças, alamedas, ruas arborizadas, pocket parks, calçadões, etc. São então estruturas espaciais que se perpetuam, típicas da cidade contemporânea, e para cada uma delas pode-se considerar que o seu desenho depende em grande parte da forma pela qual é utilizada a vegetação e portanto da postura projetual adotada.

Este artigo se propõe então a colocar algumas formas de se elaborar com a vegetação, quando em processo de projeto de um espaço livre urbano, seja ele praça, parque, etc., apresentando uma postura desenvolvida, durante o tempo de nossa prática de ensino de projeto de paisagismo para arquitetos, dentro da Faculdade de Arquitetura e Urbanismo da Universidade de São Paulo. Este posicionamento é resultado da adoção do preceito de que a vegetação é um elemento estruturador de espaços urbanos, podendo defini-los total ou parcialmente, posição esta que difere de uma visão clássica entre muitos projetistas de que as plantas, sejam elas árvores, arbustos ou for- 
rações, não passam de meros elementos decorativos, complementares a qualquer projeto seja ele de espaço livre ou edifício.
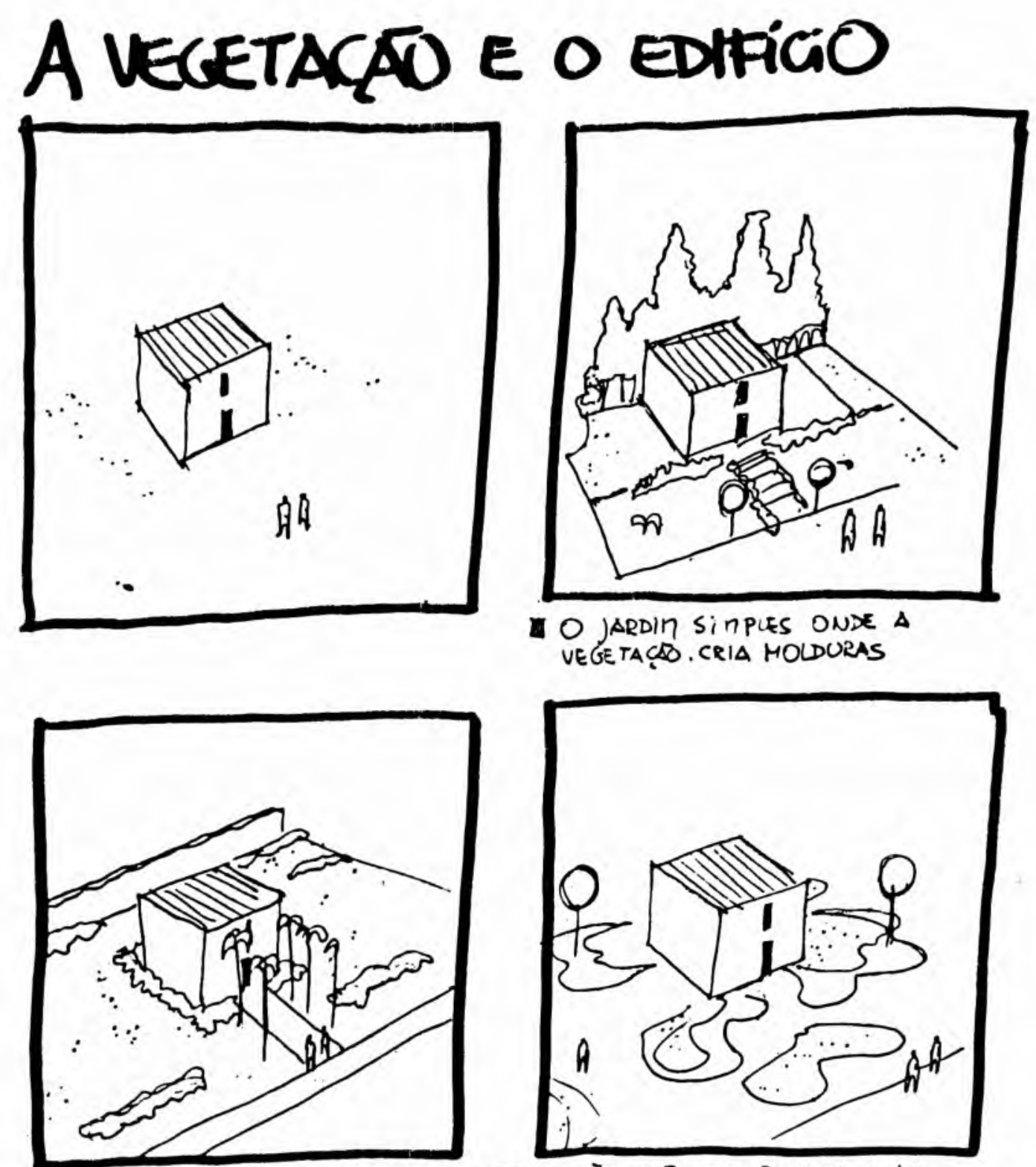

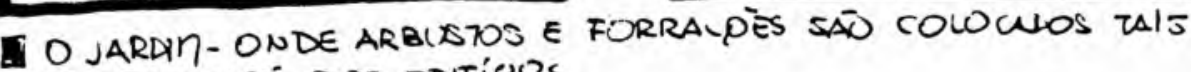
COHO RODAPES DOS EDIFIOUOS

Esta visão da planta, como elemento de fundo do edifício, como entidade a ser contida em um plano qualquer ou em um vaso, continua a ser amplamente utilizada com resultados nem sempre adequados à atual realidade projetual do moderno espaço urbano. Muito desta visão está contida em princípios estereotipados do urbanismo moderno sobre áreas verdes e que encontram sua síntese nas "cidades-jardins" e em especial em Brasília. Nesta forma de posicionamento a idéia de projeto com planos horizontais e verticais 
é simplificada dentro do conceito figura-fundo onde o edifício é a figura e a vegetação, arvoredo ou o gramado se constitui em um cenário de apoio.

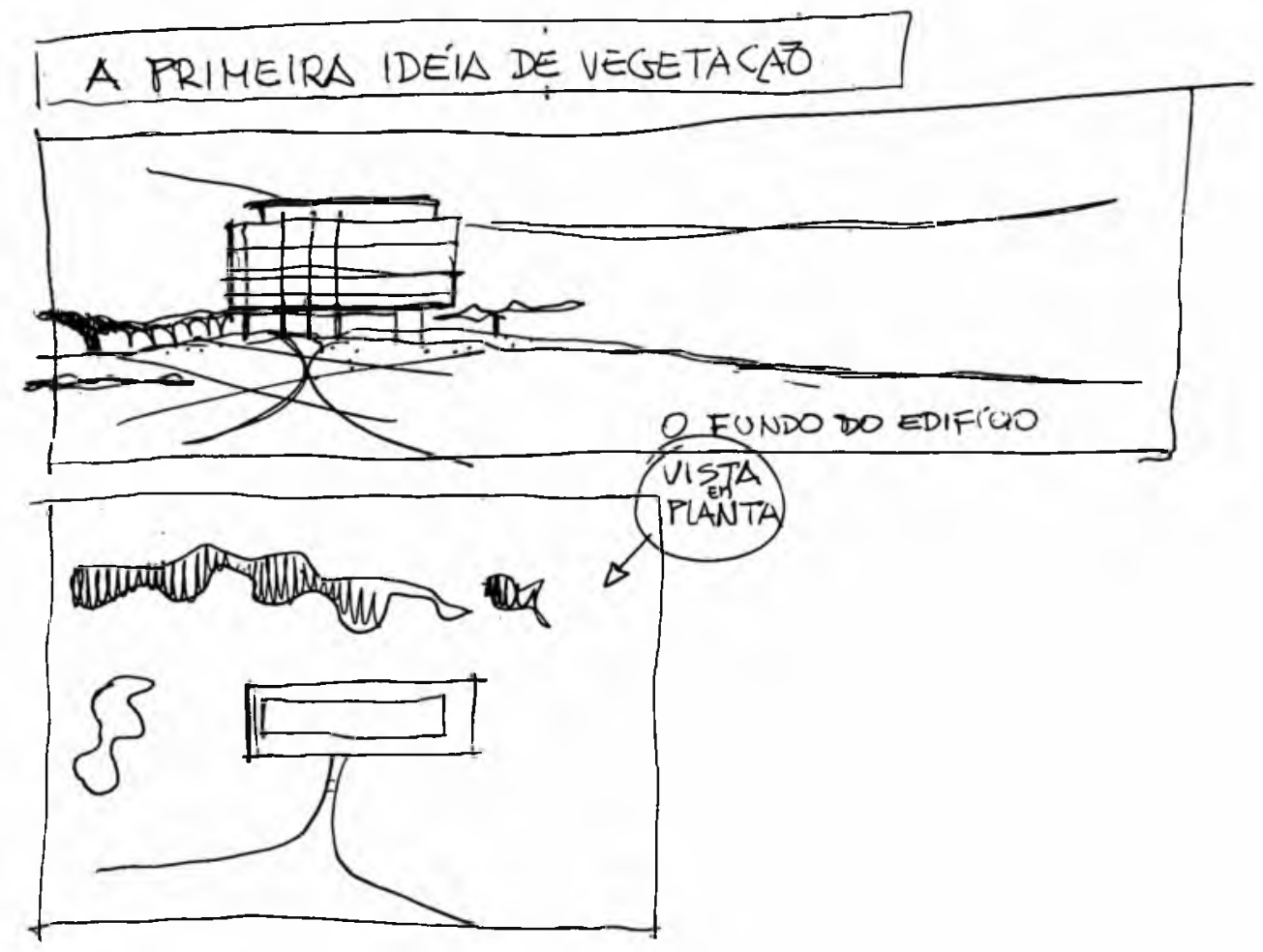

A arquitetura paisagista contemporânea, procurando se amoldar às novas formas e necessidades urbanas que se criam, indica a formulação se possível de espaços para atividades múltiplas. Utiliza-se então como princípio de projeto a criação de conjuntos de espaços articulados entre si, que na medida do possivel podem e devem abrigar no evoluir do tempo, atividades diversas. Naturalmente nem todos os espaços possuem estas características, muitos deles devendo ainda abrigar funções específicas como o lazer infantil, o play ground, mas o velho padrão de desenho é definitivamente abandonado dentro desta nova linha projetual. A figura do jardim não desaparece, muitos dos espaços livres urbanos devem necessariamente obedecer à conformação clássica do jardim, moldura do edifício, ou como certa vez afirmou em tom de galhofa um arquiteto paisagista como "rodapé de prédio". Seriam os casos das pequenas áreas para plantio de flores ou dos espaços em torno de alguns tipos de prédios públicos, como os de Brasília por exemplo, especialmente o belíssimo jardim do Palácio do Itamaraty de autoria de Roberto Burle Marx.

\section{PENSANDO O ESPAÇO ... E A VEGETAÇÃO}

São diversas as formas pelas quais se pode encarar a concepção de um projeto de espaços livres. De um modo simplificado pode-se fazer uma analogia 
do espaço livre com uma figura geométrica, no caso o cubo, pois como ele todo espaço possui paredes, tetos e pisos, isto é vedos, coberturas e pisos.

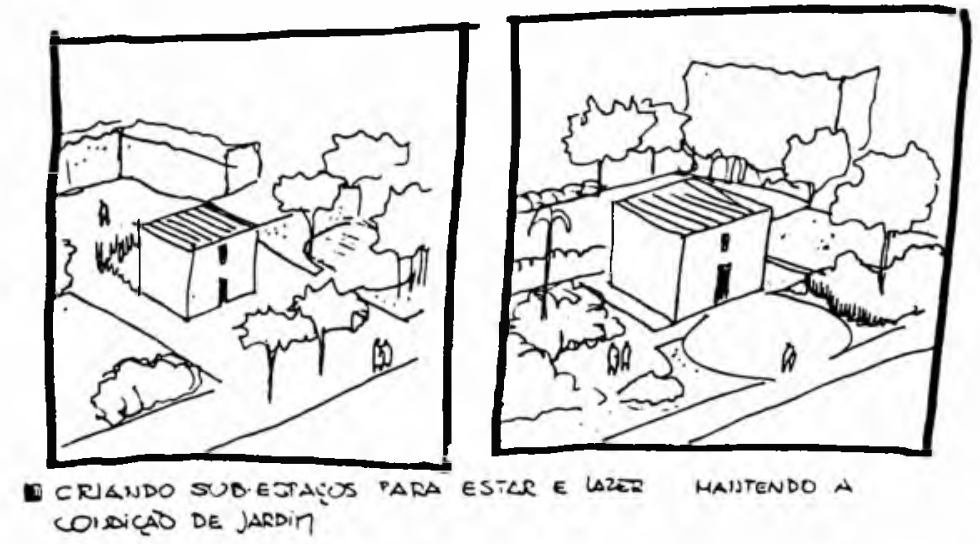

No caso de uma rua, as paredes, os planos verticais, os chamados vedos são definidos pelas edificações por muros, por touceiras de arbustos e pela arborização (os troncos). No caso de uma praça, edifícios e vegetação são seus elementos definidores e assim por diante.

Os planos horizontais tetos e pisos podem ou não ser definidos por vegetação, no caso os tetos seriam as copas das árvores, ou se construídos pérgolas, marquises e pórticos. Como regra, todo e qualquer plano horizontal superior no projeto de espaço livre deve ser pensado como o céu infinito, como teto já que este é a "cobertura" convencional deste tipo de espaço.

Quanto aos pisos, planos horizontais inferiores, somente em parques e grandes jardins podem e devem ser estruturados totalmente por vegetação, forração no caso, em geral sendo definidos nas cidades por pavimentos.
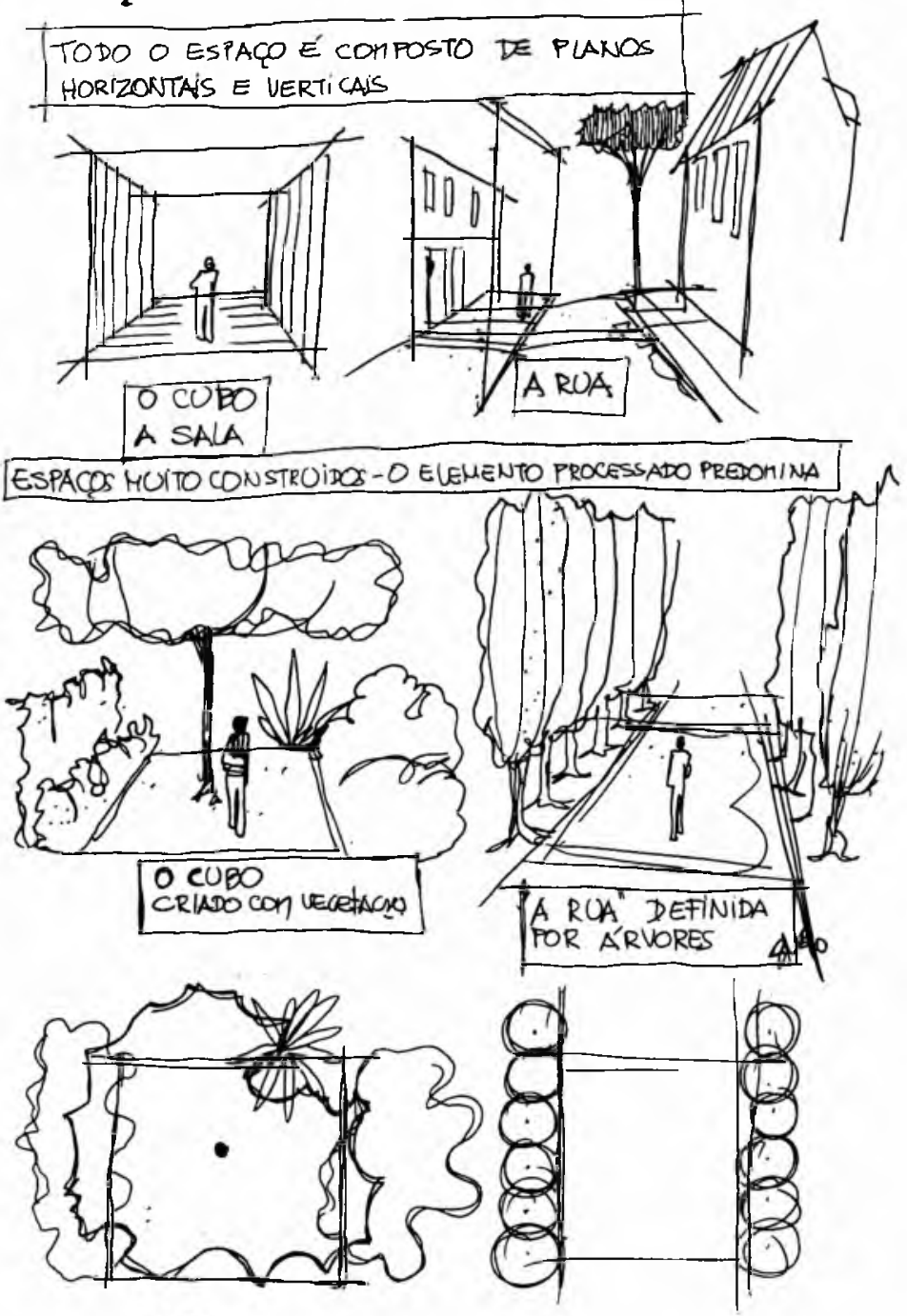

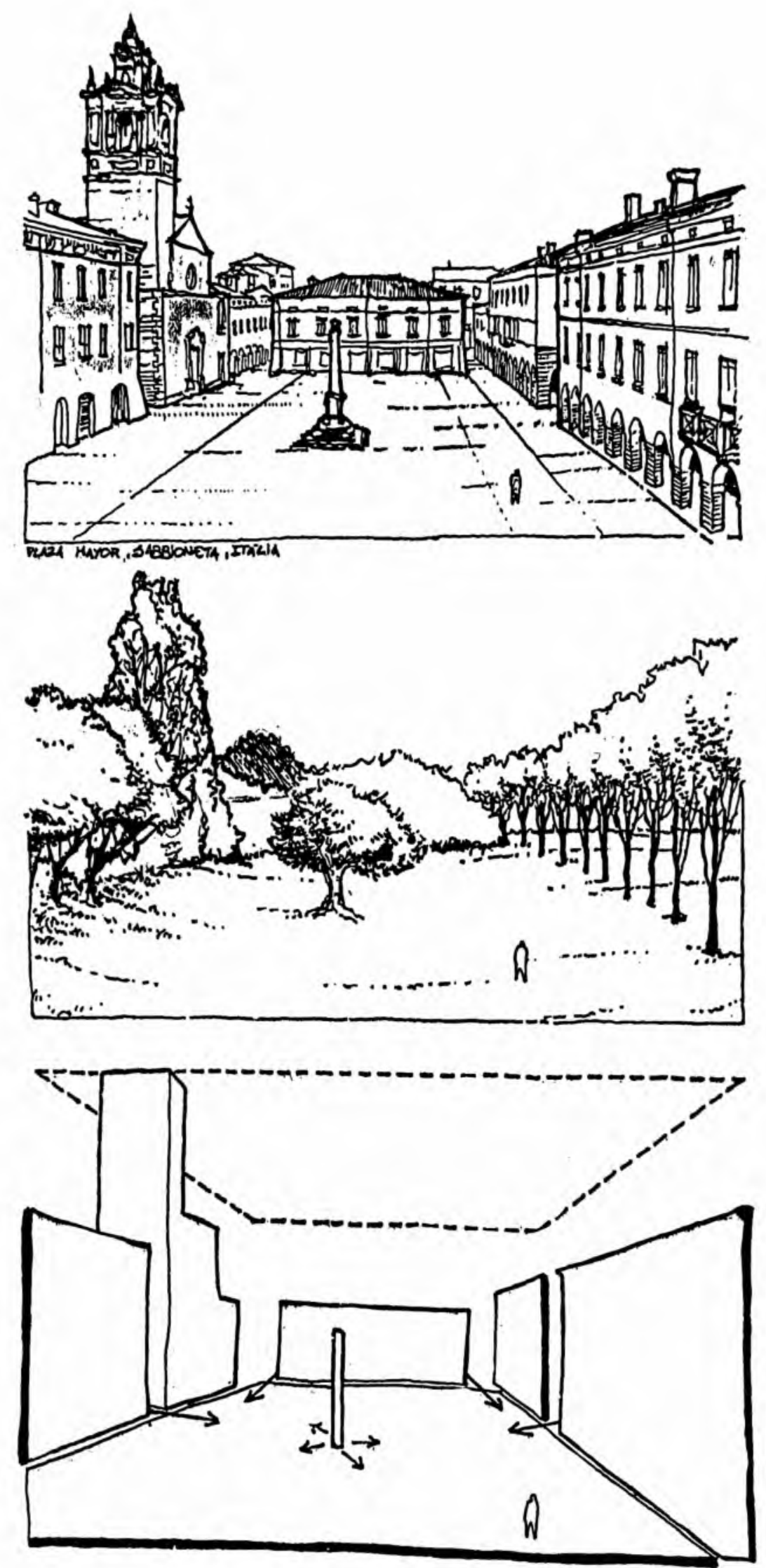


\section{O PROJETO COM VEGETAÇÃO E SUAS POSSIBILIDADES}

Projetar com vegetação significa trabalhar em cumplicidade direta com seres vivos que crescem e se desenvolvem com o correr do tempo, criando e recriando espaços a cada nova estação. Se as árvores demoram a crescer, a tomar corpo, arbustos e forrações, se bem cuidados, crescem e tomam forma rapidamente, dando um caráter preliminar ao espaço no seu tempo de plantação e neste momento criando condições mínimas de ocupação. $O$ arvoredo possui um tempo maior de maturação e só se observa um amadurecimento de sua estrutura após alguns anos de plantio. Algumas espécies demoram até dezenas de anos para chegar a fase adulta como as figueiras (Ficus bejamin) que, por exemplo, demoram cerca de 30 anos para assumir todo o seu porte, chegando a possuir 15 a $20 \mathrm{~m}$ de diâmetro.

Estes fatos nos levam a indicar que se pense o projeto dos espaços livres em etapas ou momentos diversos de maturação, de modo que ao se abrir determinado espaço ao uso público este já esteja apto ao desempenho das atividades humanas, independentemente do porte das diversas espécies ali colocadas.

Os croquis exemplificam as diversas etapas de amadurecimento de um espaço totalmente estruturado por vegetação e sugerem no caso as possibilidades cênicas de cada um. No tempo 1 com certeza se apresenta uma situação pobre em termos cênicos, um campo exposto aos ventos e ao sol onde um pedestre dificilmente se sentirá a vontade, enquanto nas outras duas situações tempos 2 e 3 os espaços já estão devidamente estruturados e articulados entre si e com certeza permitem ao usuário um maior conforto e possibilidade de orientação.

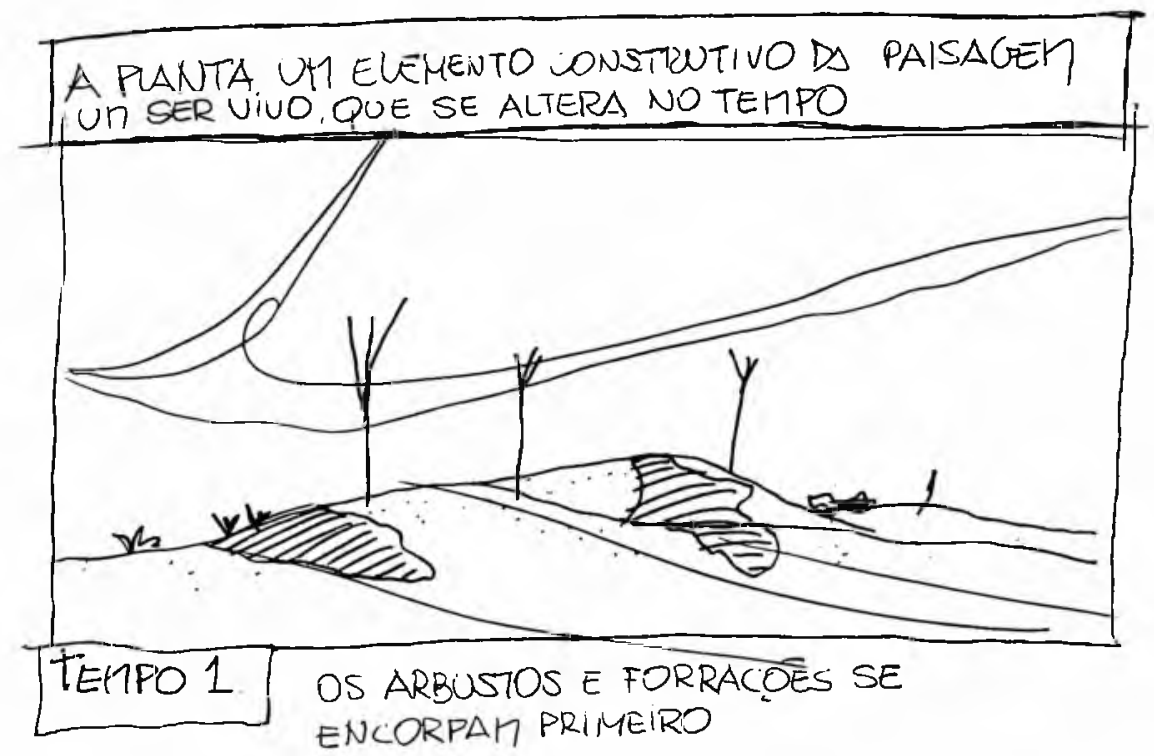




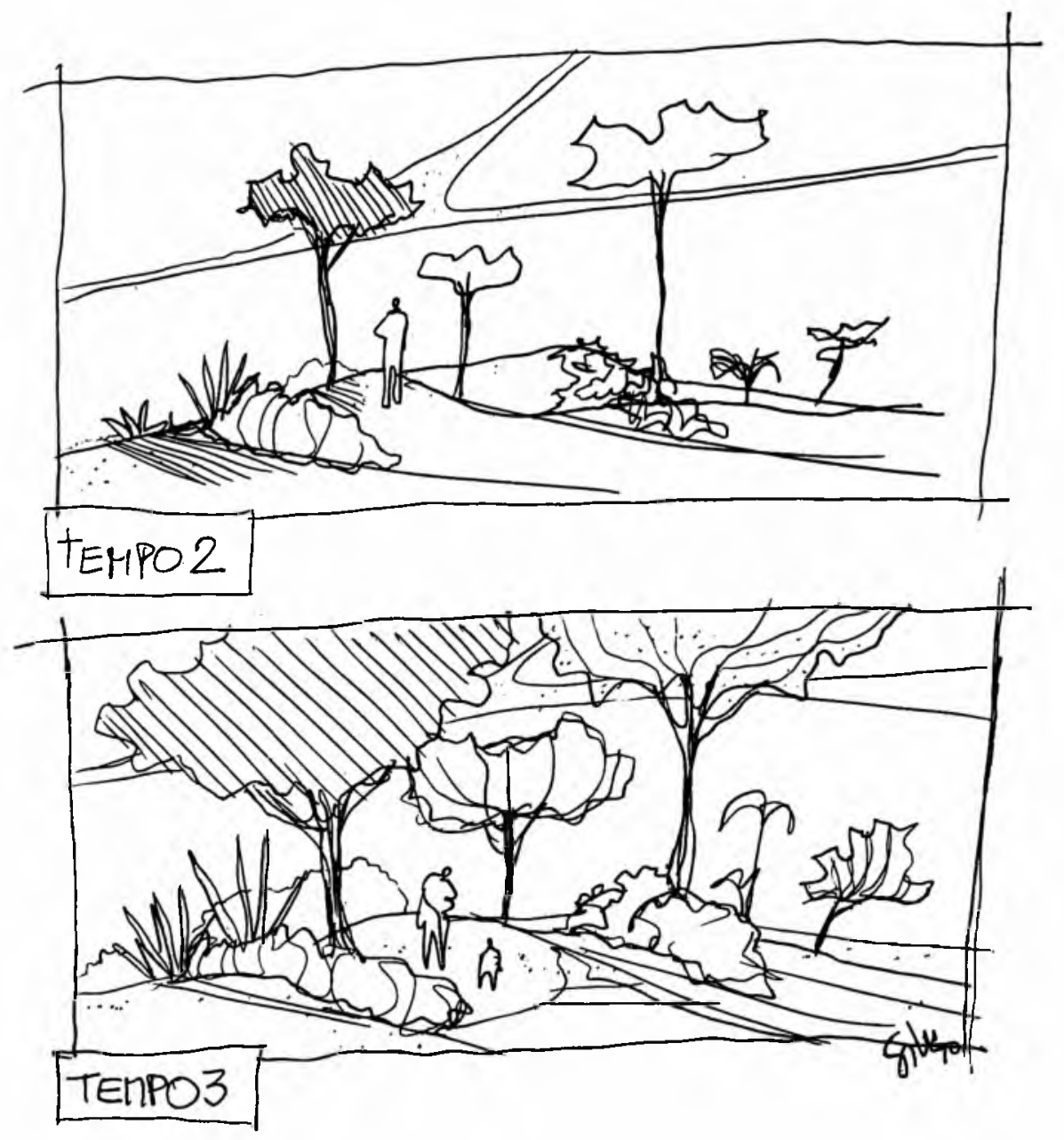

Certamente espaços paisagisticamente bem estruturados devem apresentar, desde o seu tempo 1, para o usuário, as melhores condições de usufruto, tanto a nível funcional ambiental, como cênico. $O$ que se observa, entretanto, e que muitos dos projetos são concebidos em sua forma final, sem se ater ao fato das diversas fases de maturação do espaço.

Como com qualquer elemento configurador de espaços, o projeto com plantas oferece infunitas possibilidades de desenho com os mesmos elementos. $O$ mais clássico partido adotado, derivado dos tradicionais jardins dos períodos medieval, renascentista e barroco indica como critério-base a colocação de um elemento mais alto no meio, quase uma escultura, cercado por outros tantos mais baixos. Este critério por décadas dirigiu e dirige a concepção da praça tradicional brasileira, limitando as opções de uso à circulação e ao sentar em bancos periféricos aos canteiros. 


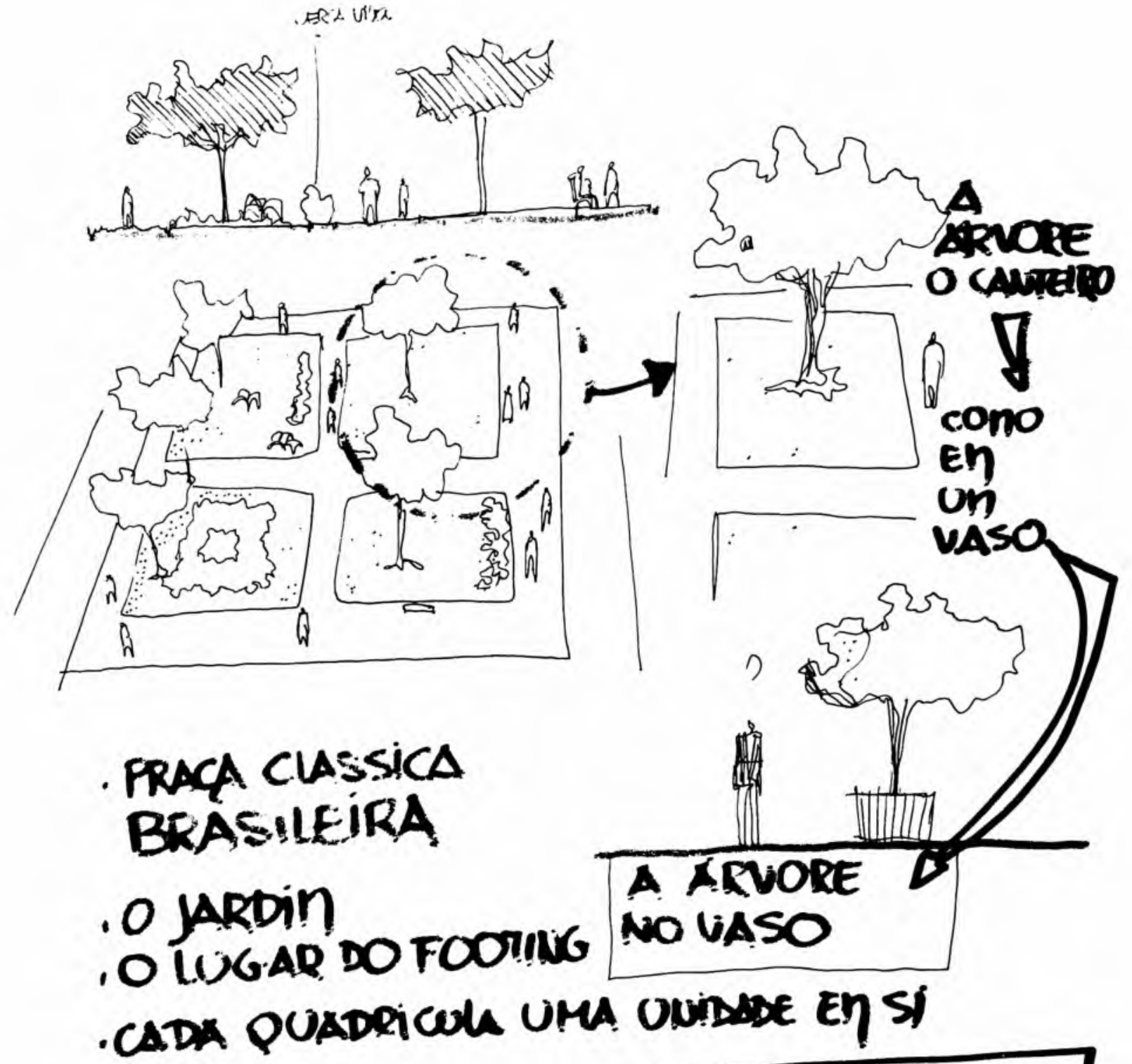

\section{O PARCELAYENTO DA PRACA}

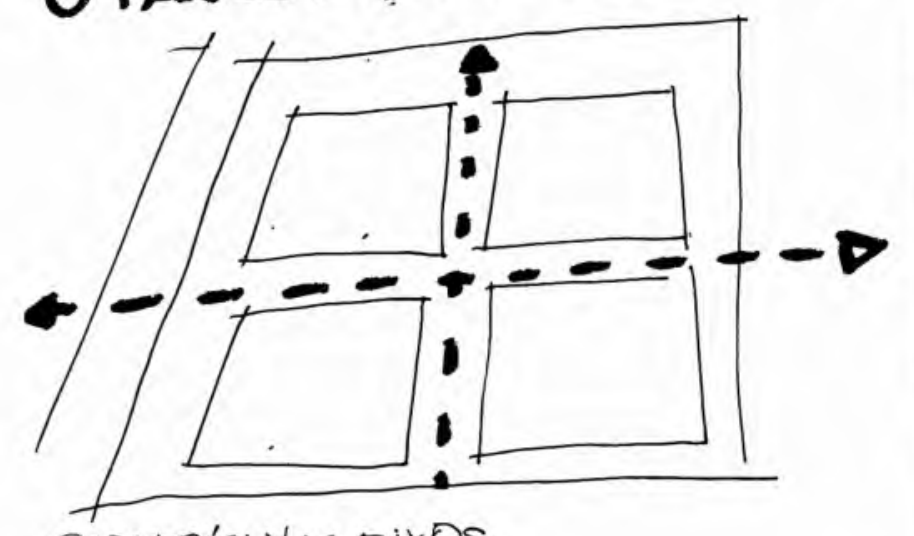

QUADRÍCULASIEIXOS
OPGẼES DE USO

- circular

- sentar ey bancos

NA PERIFERIA DAS OUA- DRICULAS

Dificulta-se a

LRIACAO DE SUB.ESPACOS

E A'REAS DE ENCONTRÓ 
O uso de formas diversas de agenciamento só foi introduzido na metade do séc. XX e ainda não são formas de opções aceitas por todos, especialmente por falta de conhecimento de tais possibilidades. Estas formas permitem a criação de múltiplos espaços de estar e circulação, que se contrapõem totalmente às limitadas possibilidades dos padrões tradicionais, aumentando em muito as alternativas do arquiteto da paisagem no seu ato de projetar.
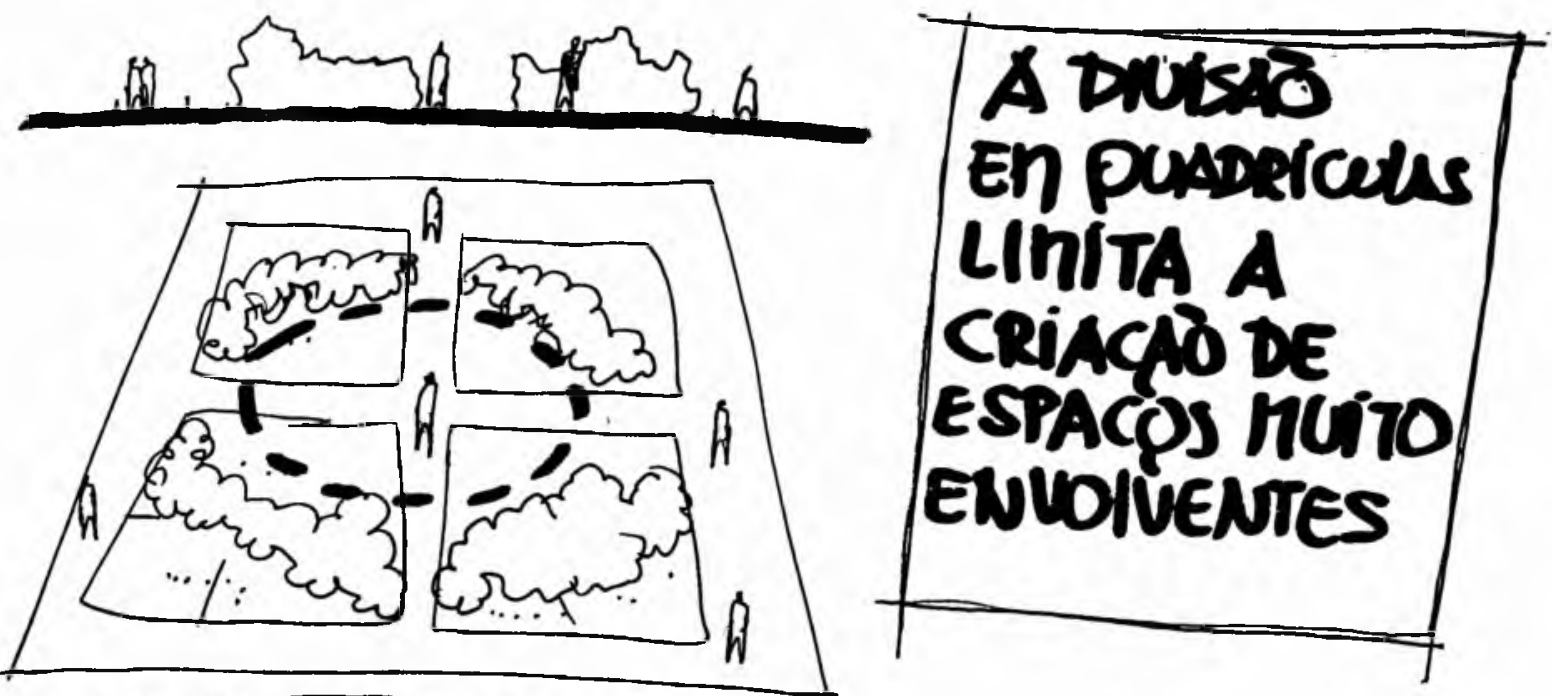

ELABORACQAO CON ARBUSTOS

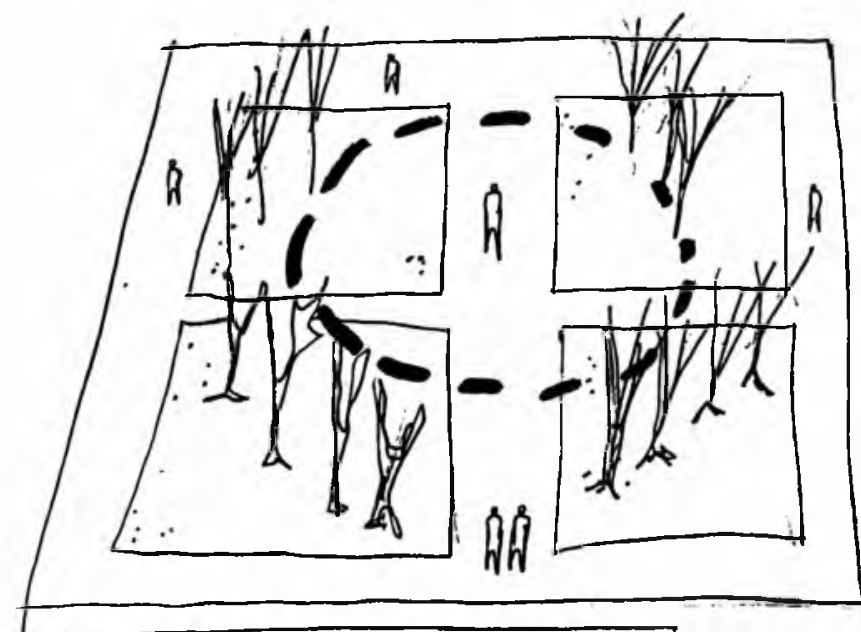

ELABORACৃAOA COM ÁRVORES

MESNO PUE SE crien OPCPE DE PLWTIOO RESUIZDDO SERA

- RESDO

UnESPACO

$\triangle D E P U D O$ PARA

circulaca.

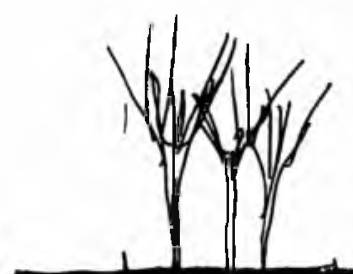

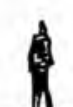

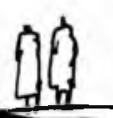


Estes critérios alternativos podem ser adotadọ tanto na concepção de uma praça, como se observa nos esquemas gráficos, como no agenciamento de canteiros, parques e demais espaços livres.
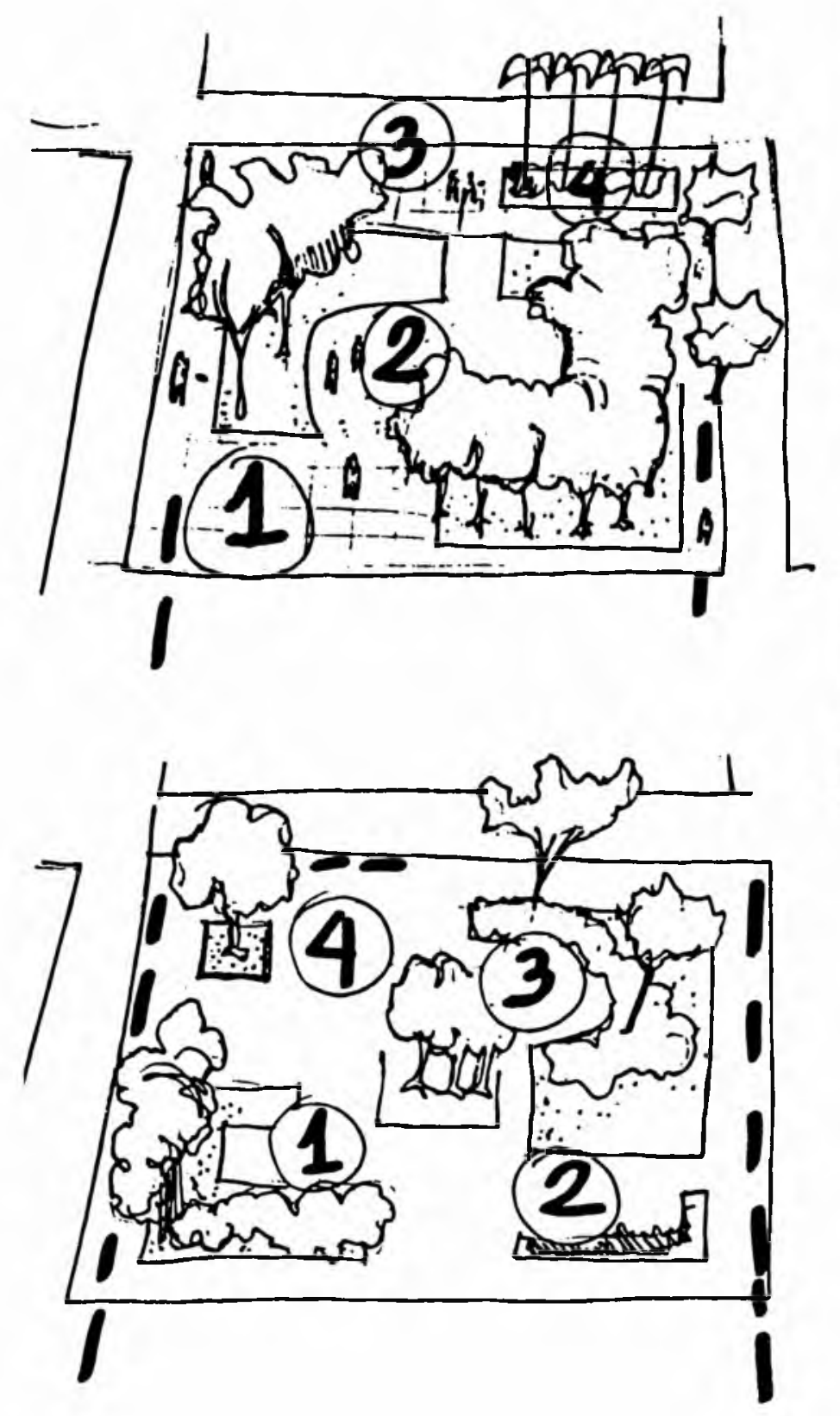

O ABANDONO DO RETICULDO PODE FAVORECER A CRIACAO DE DIFERENTES SUB-ESPACOS PUE SE SOMAM AOS TRADICIONALS ESPACQS DE circulaca perIFÉRICOSAs calcadAs 
A praca, o canpo e o parpue en contraponto
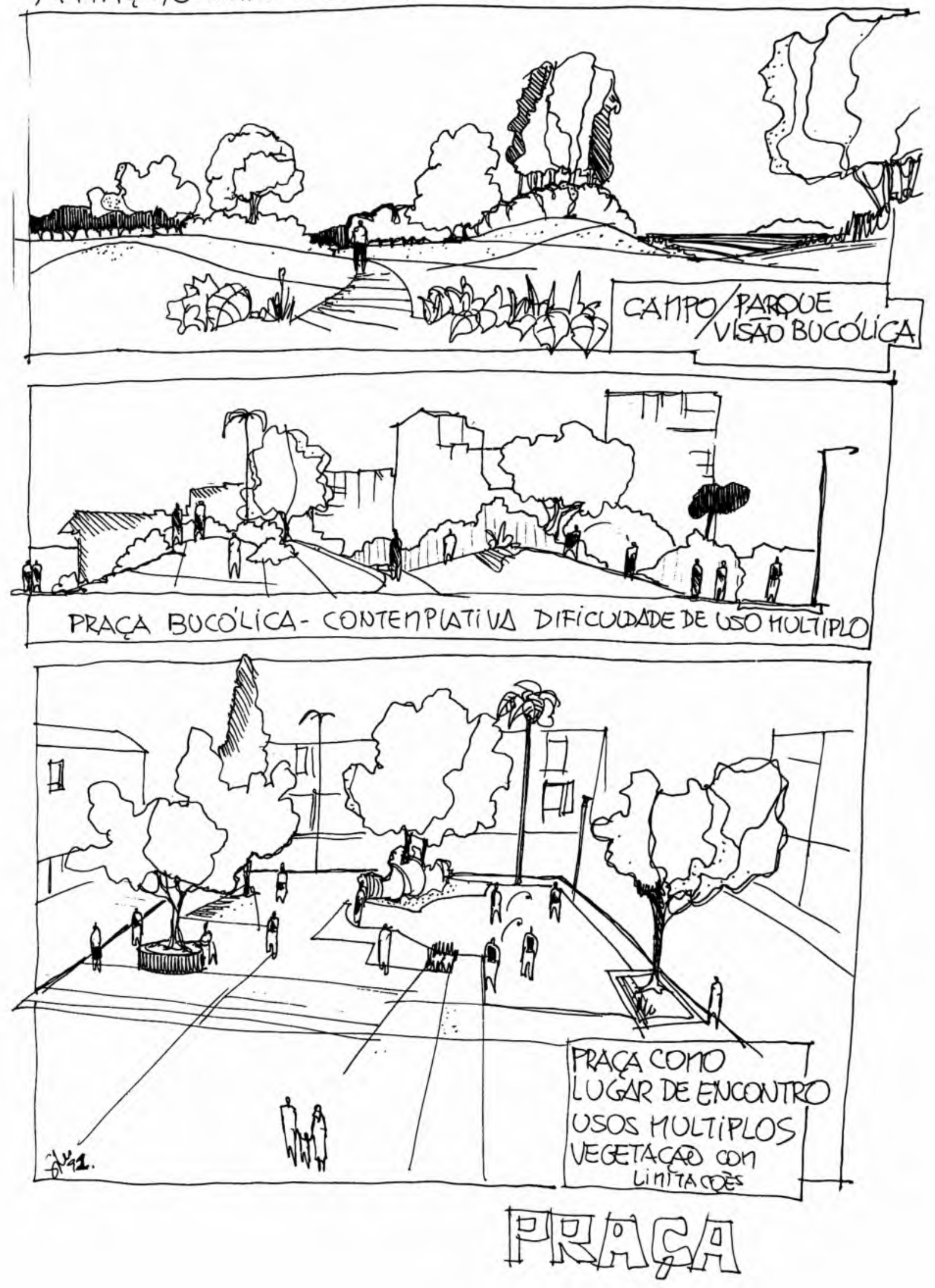

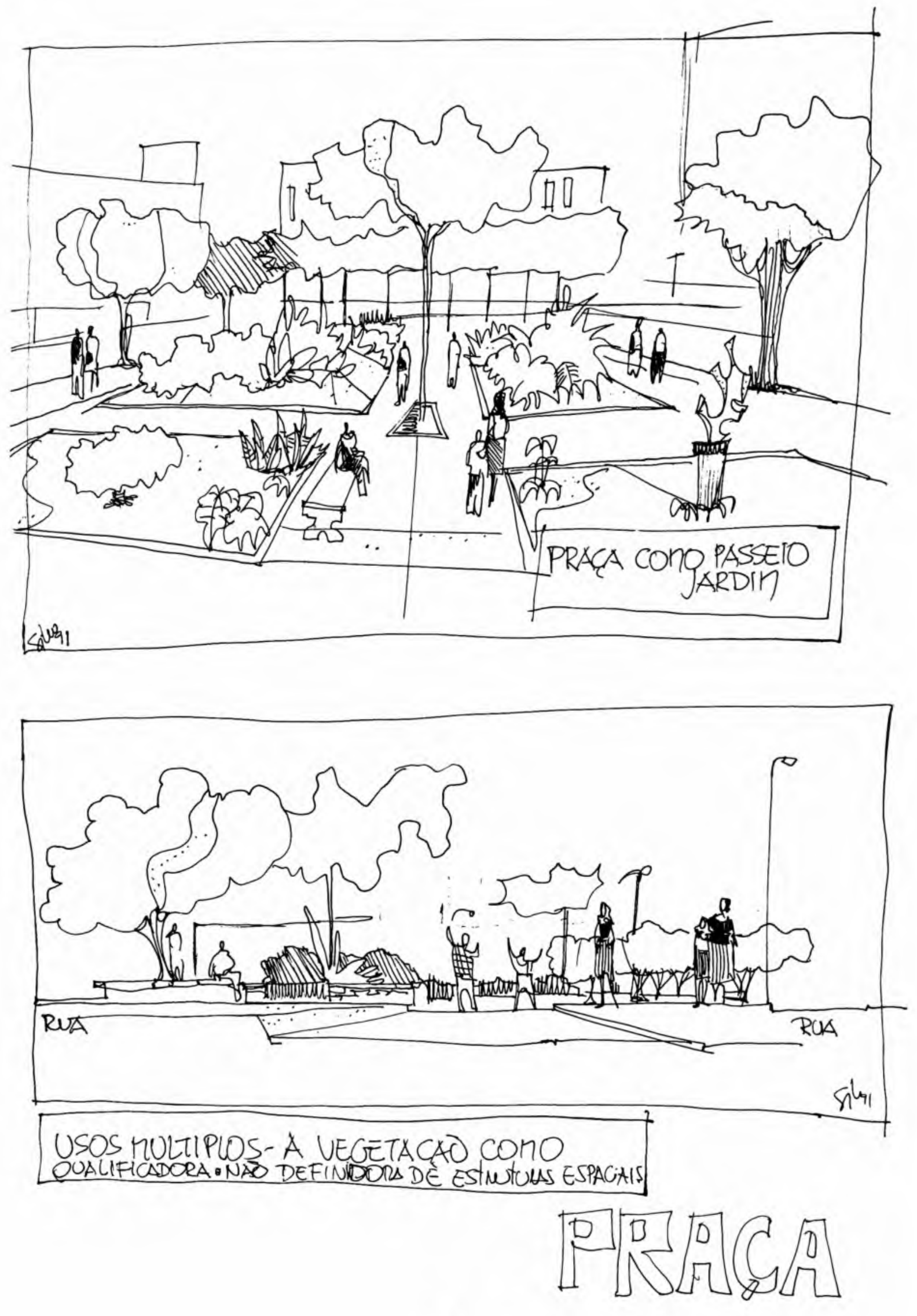
Se por exemplo desejamos organizar um espaço qualquer, como o campo a seguir, com árvores de dois diferentes formatos (cilíndricas e tipo "palmeiras") arbustos e relvados, as possibilidades de organização são com certeza das mais diversas, da mais óbvia e clássica até muitas outras mais.

Todo o trabalho com vegetação na realidade se estrutura na organização de maciços de árvores ou de arbustos associados entre si ou não, sempre relacionados com as situações de relevo e com os pisos, formações ou pavimentações. Podem os elementos-indivíduos, árvores ou arbustos, eventualmente, de acordo com a intenção projetual, encontrarem-se também isolados dentro do espaço, então colocados como elementos balizadores e escultóricos.

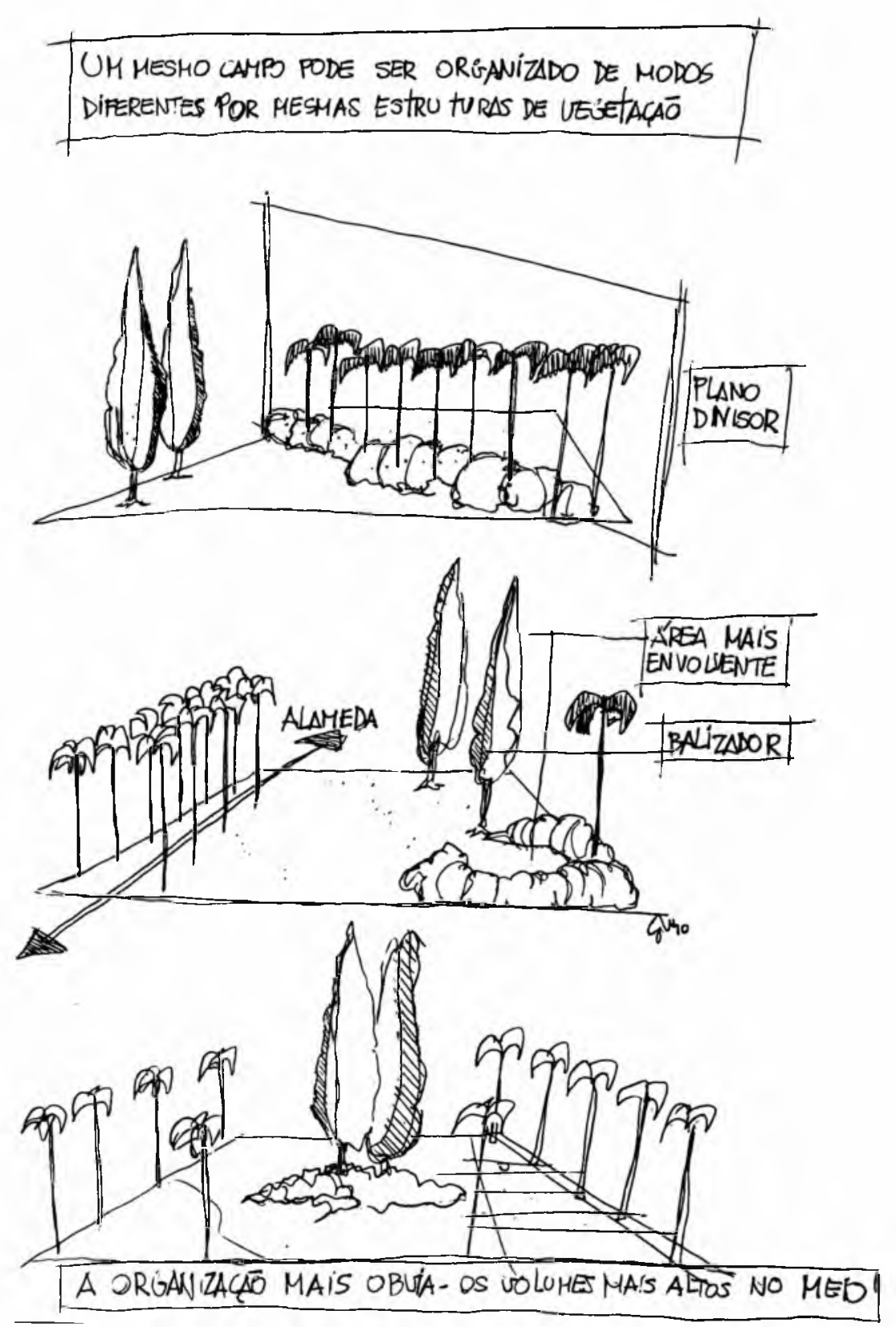




\section{A SELEÇÃo DO MATERIAL E O PROJETO}

Dentro do território brasileiro inúmeras são as formas de associação vegetal encontradas, da típica Mata Atlântica aos extensos cerrados e coqueirais característicos das praias quentes do Nordeste do país e todas estas formações sugerem muitas alternativas a se adotar, parcial ou totalmente, em um projeto.
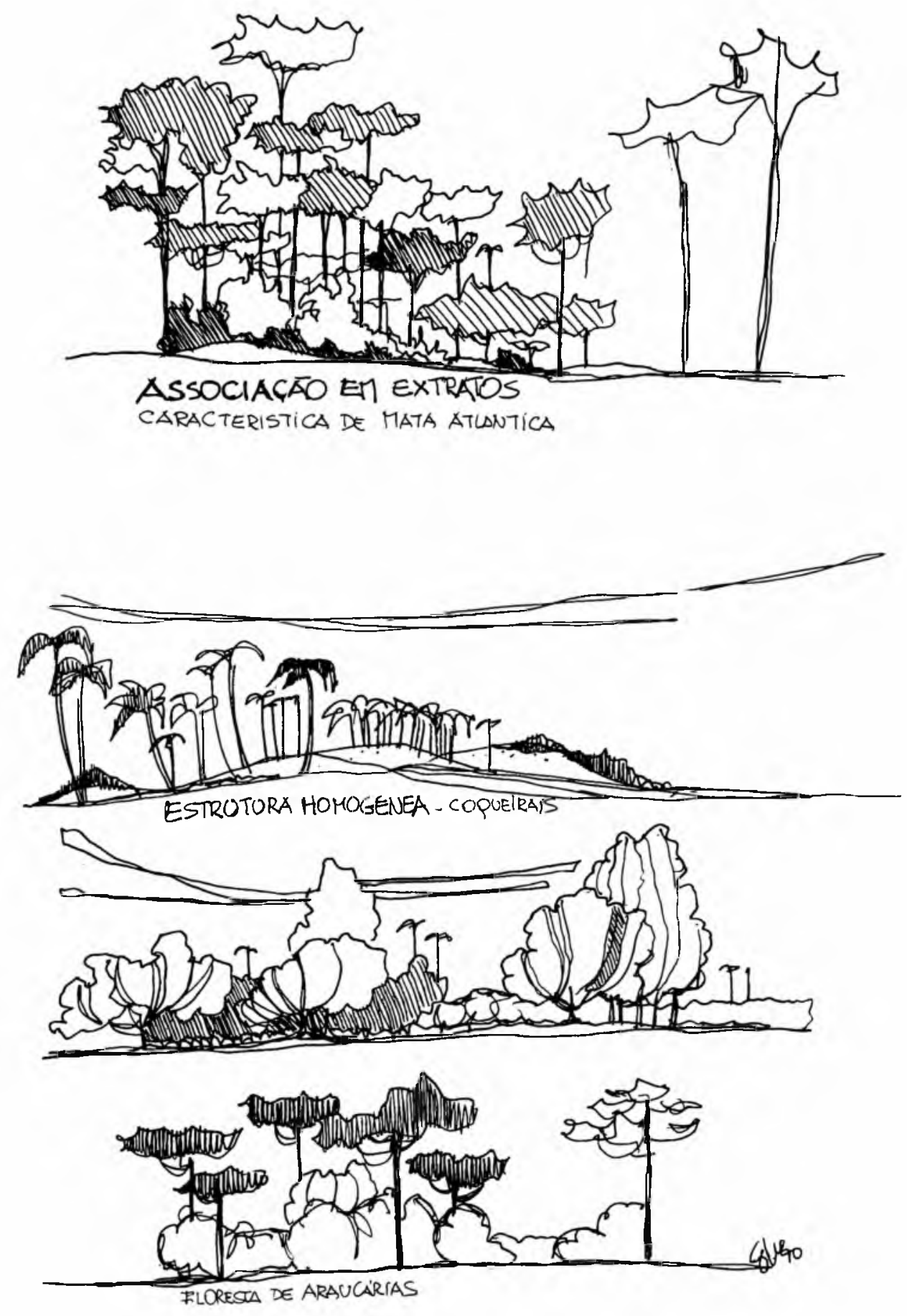
Tem-se que um dos princípios básicos da moderna arquitetura paisagística brasileira prescreve a adoção exclusiva de espécies nativas do país em todo e qualquer projeto. São utilizadas freqüentemente espécies oriundas da Mata Atlântica, muitas delas facilmente adaptáveis às áreas urbanas, do cerrado e outras vezes espécies advindas da Mata Amazônica. Esta postura que favoreceu e favorece à criação de um repertório próprio ao país em termos de elementos de desenho dos projetos paisagísticos (no caso os jardins e parques) foi radicalmente defendida e adequada pelos paisagistas modernos, no período entre os anos 50 e 80 , e é atualmente de certo modo criticada em seu exagero.

Este fato se deve principalmente à percepção que se tem hoje da extrema adaptabilidade às condições climáticas do país de um sem número de elementos vegetais importados, eucaliptos, pinheiros, coqueiros e muitos mais, que já foram assimilados pela cultura popular e podem sempre colaborar na formulação e configuração das áreas livres e da paisagem como um todo.

De qualquer modo, esta posição de se aceitar uma "mistura" de espécies não pode limitar a pesquisa de novas espécies brasileiras a serem incorporadas ao repertório do projeto de plantação do Brasil, que deve sempre ser incentivada, pois a existência de novas linhas projetuais se favoreceu enormemente com a adoção preponderante de plantas típicas e suas associações, criando condição para isso e determinando a formulação de uma identidade própria do projeto paisagístico brasileiro, antes quase que limitado à cópia de manuais ingleses e franceses.

\section{OS VEDOS - ÁRVORES E ARBUSTOS}

A partir, então, da idéia que se pode organizar espaços exclusivamente por intermédio da vegetação, tem-se que neste universo árvores e arbustos podem ser considerados os elementos básicos para a constituição dos vedos ou planos verticais. Tanto uns como outros, oferecem diversas possibilidades e formas de organização espacial e nestes casos sempre existe a contraposição dos padrões clássicos aos modernos.

No caso da arborização à tradicional e convencional forma de agenciamento de árvores isoladas, mais ou menos eqüidistantes umas das outras, ou alinhadas em aléias bem comportadas pode-se contrapor a idéia da criação de planos diversos, que por si só podem definir pátios, clareiras, caminhos, etc.

Esta primeira idéia de arvoredo plantado separado, cada elemento eqüidistante de seu vizinho é facilmente encontrada na maioria dos espaços urbanos projetados por leigos ou projetistas pouco informados das possibilidades de 
plantio e portanto de criação de planos e espaços com as árvores. Os desenhos a seguir mostram algumas possibilidades de arranjo, desde a forma mais clássica, encontrada inclusive nos jardins da Universidade de São Paulo e no Parque da Quinta da Boa Vista (Rio de Janeiro). Em muitos casos esta indicação de adoção de outras formas de organização espacial não implica necessariamente na exclusão das tradicionais, que devem sempre continuar a fazer parte de um repertório projetual de qualidade, que quanto maior e mais diversificado melhor poderá atender às necessidades de cada situação.
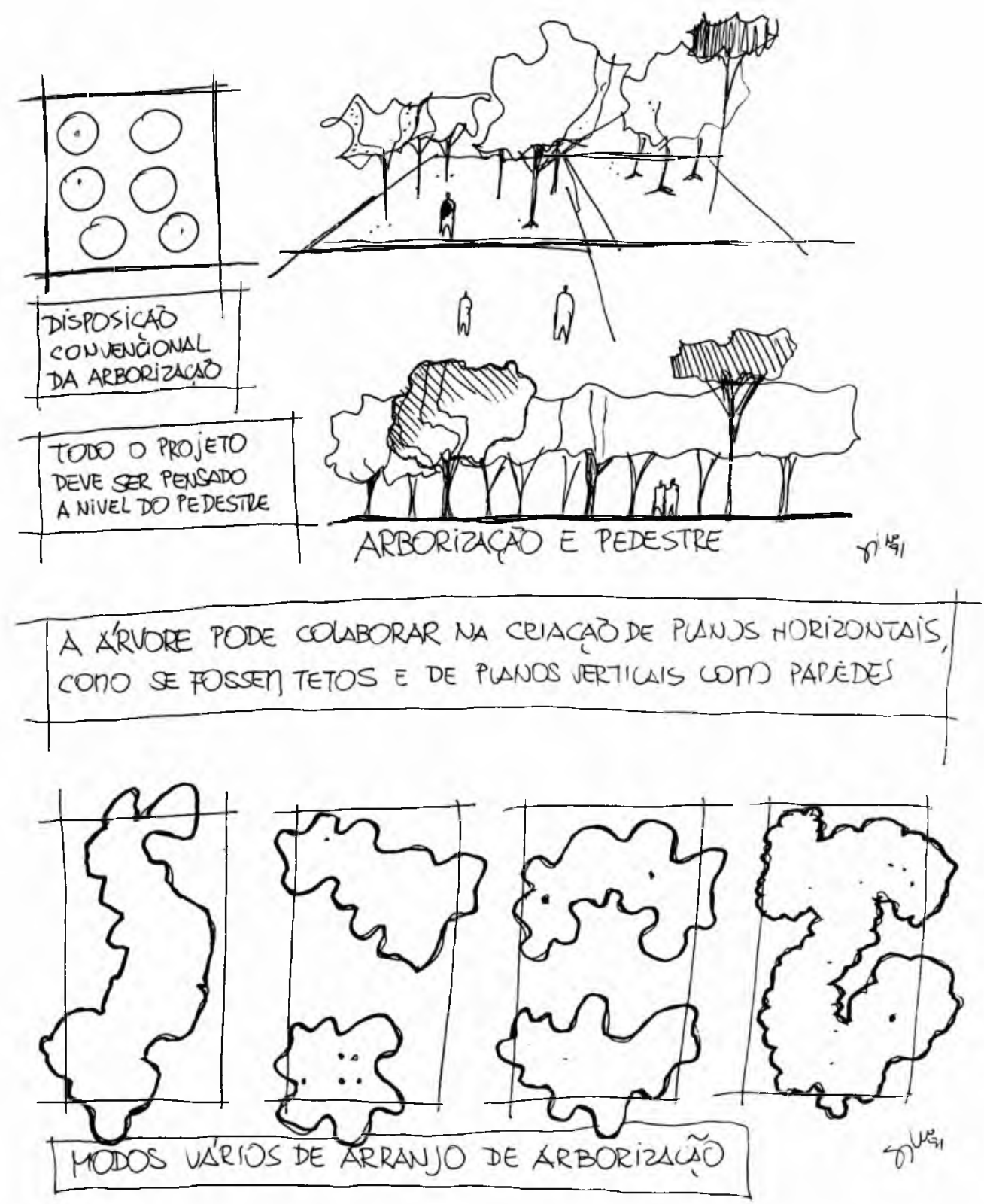

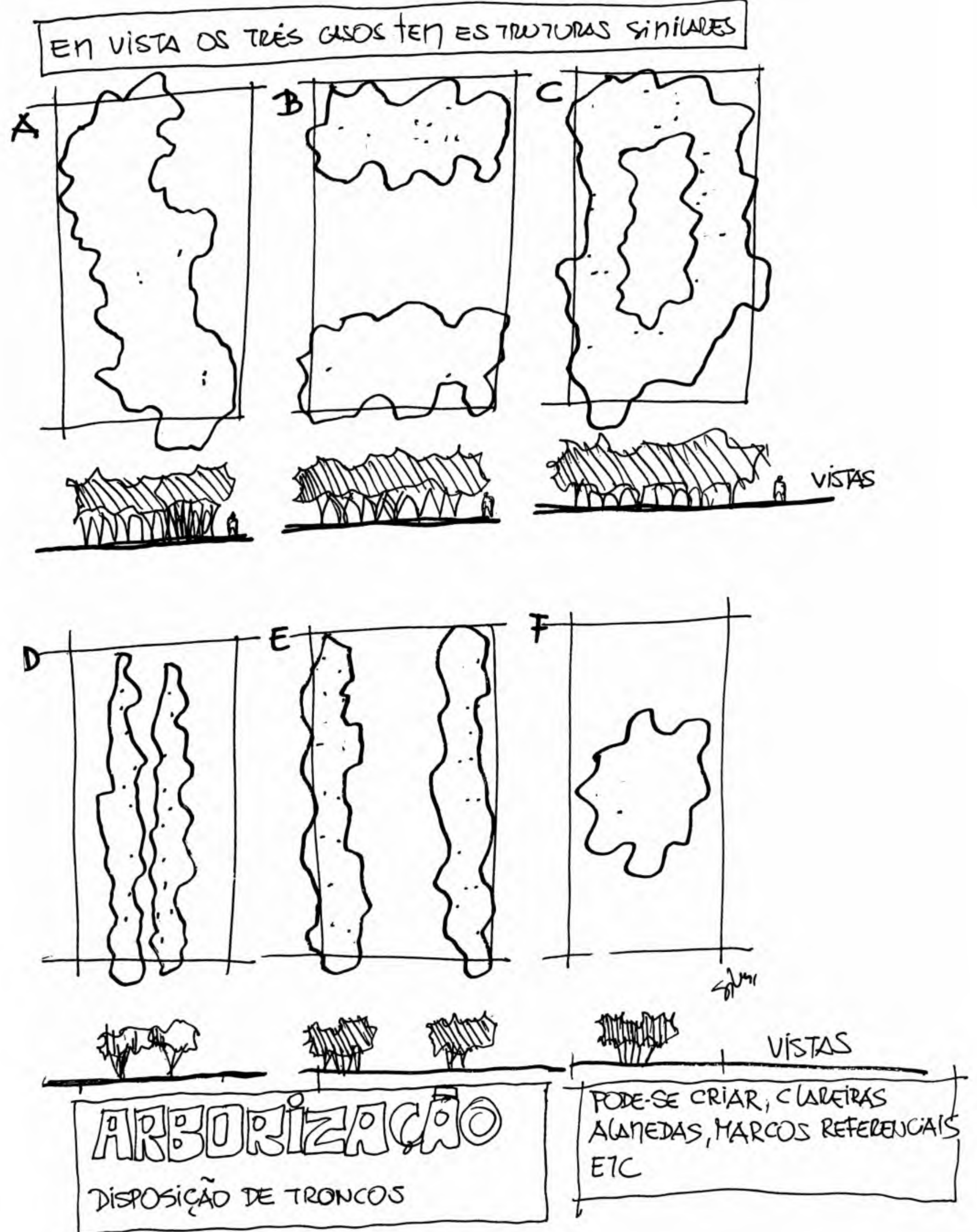


\section{VOLUMETRIA}

As árvores na concepção de projetos paisagísticos podem ser associadas a alguns tipos-padrão de volume. Estes caracterizam-se basicamente pela forma de suas copas que podem ser cilíndricas, cônicas, em leque, etc. e quando associadas entre si oferecem múltiplas possibilidades na criação de ambientes, ora muito sombreados, ora muito claros, ora muito envolventes ao usuário, e possibilitam diversas formas de circulação por entre seus troncos.

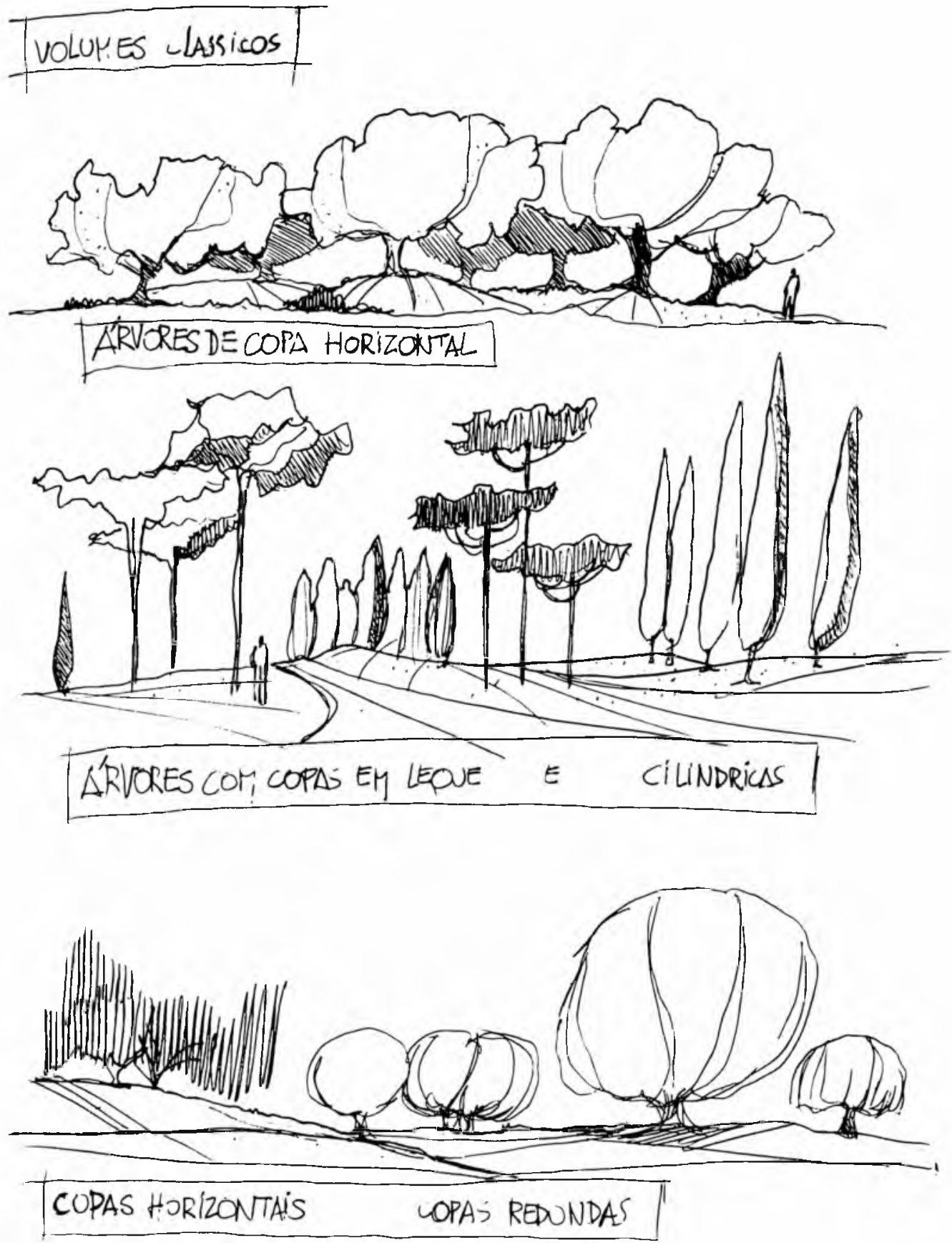




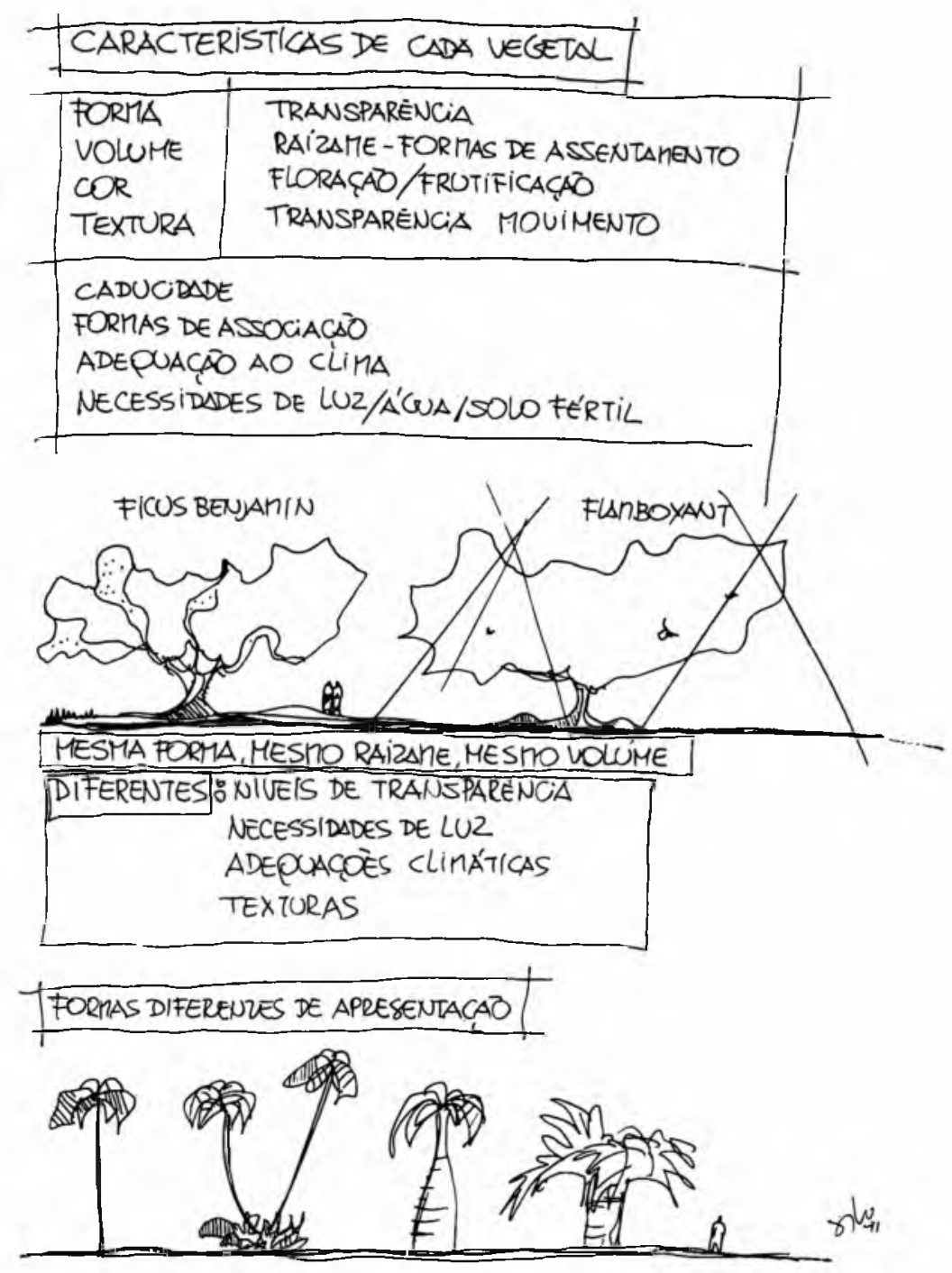

\section{DISTANCIAMENTO}

O fator distanciamento constitui-se outro elemento fundamental no projeto com plantas especialmente no tocante às árvores em especial. Geralmente o projetista iniciante se atém ao projeto da área recoberta pelas suas copas e esquece que o espaço está sendo construído para pessoas às quais será oferecida a alternativa de circular ou não em meio aos seus troncos. Este fato, da não percepção da importância do distanciamento, se justifica por uma visão tridimensional limitada do espaço a ser projetado e do produto final desejado, pois se projeta "convencionalmente" pensando-se nas árvores como cobertura, teto, e se minimiza a importância da sua percepção pelo usuário, sempre um pedestre, sempre em confronto com planos verticais, constituídos também por troncos!!! 


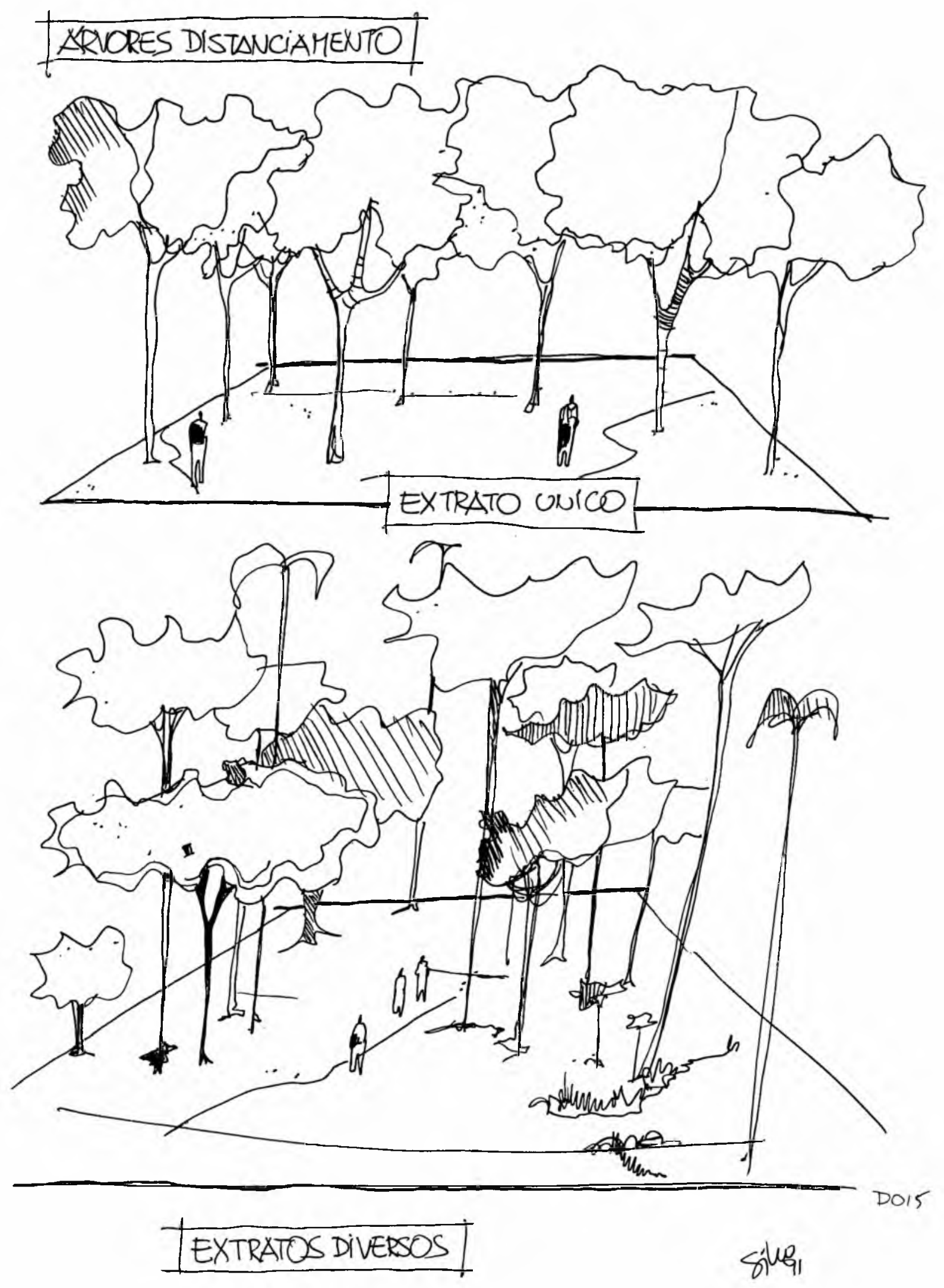


Quanto mais próximos os troncos, naturalmente mais difícil será o caminhar e maiores e mais extensas poderão ser, conforme o caso, as áreas de sombra.

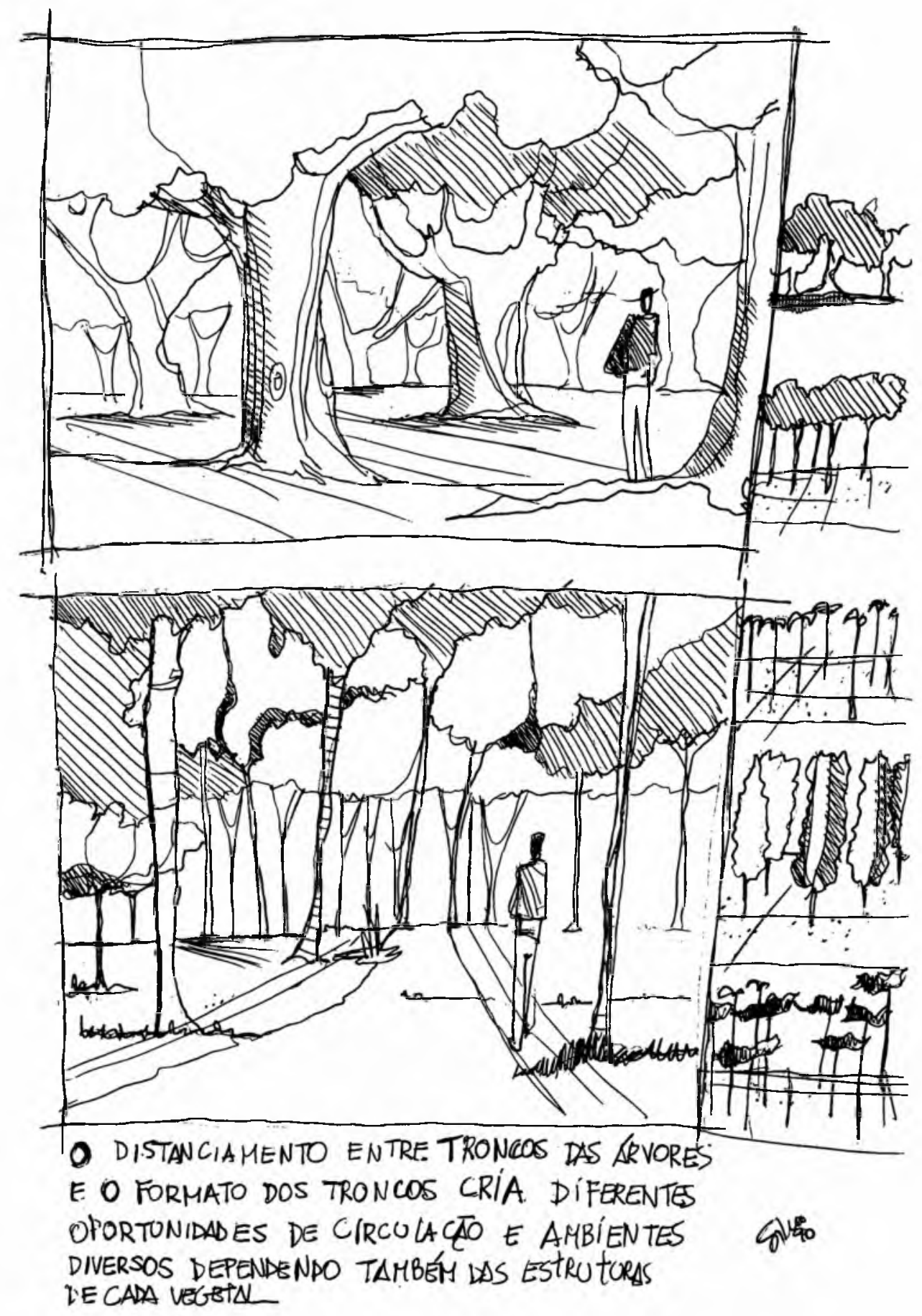

No caso de coqueirais as possibilidades de circulação e sombreamento serão sempre amplas devido a própria forma de agenciamento desejável para estas estruturas, enquanto que em um bosque organizado em estratos diversos, o caminhar será muito dificultado. Além do distanciamento, outros fatores 
contam no projeto de plantação com vegetação e devem ser constantemente repensadas como:

1. Adequação ao solo: mesmo que a planta, no caso árvore, arbusto, etc. pertença a província vegetal correspondente à área em que está localizado o terreno, este se estiver empobrecido, ou por exemplo se constituir em cobertura de um aterro sanitário, terá dificuldades de aceitar um plantio e deve ser adequadamente tratado para receber qualquer plantação.

2. Formas de associação: possíveis geneticamente, nem todos os vegetais podem conviver uns com os outros e, sendo que na competição por espaço, muitos podem ser eliminados por seus oponentes, prejudicando a concepção original do projeto, de modo que um conhecimento prévio das espécies a serem implantadas é indispensável.

3. Orientação solar: como na produção de um projeto de arquitetura é fundamental em um projeto de plantação o posicionamento dos seus elementos, especialmente vegetais em relação ao Sol, tanto em questão da sua sobrevida, pois existem aqueles indivíduos que necessitam da luz solar, ou aqueles que necessitam de sombreamento total, tanto na criação de espaços mais ou menos ensolarados para o usuário (um parque infantil deve por exemplo possuir muitas áreas de meia sombra de modo a proteger as crianças dos efeitos nocivos da radiação solar em horários de Sol a pino).

\section{ARBUSTOS}

No caso do trabalho com arbustos estes se apresentam no imaginário de um observador comum sempre de uma forma típica, ou como elementos criadores de cercas vivas ou como elementos balizadores, escultóricos de gramados e canteiros, pois é desta forma que são utilizados tradicionalmente em nossas cidades, nos jardins públicos ou privados.

Adotando-se os pressupostos colocados anteriormente, também com arbusto existe a possibilidade, de por intermédio de outras formas de agenciamento, da criação de espaços e subespaços diversos.

Esta é uma forma de agenciamento ainda pouco explorada no país, pois somente alguns paisagistas tem em sua obra exemplos significativos de uso da vegetação arbustiva com o objetivo da criação de espaços e subespaços, como é a caso de Roberto Burle Marx, Roberto Coelho Cardoso, Benedito Abbud e outros. 


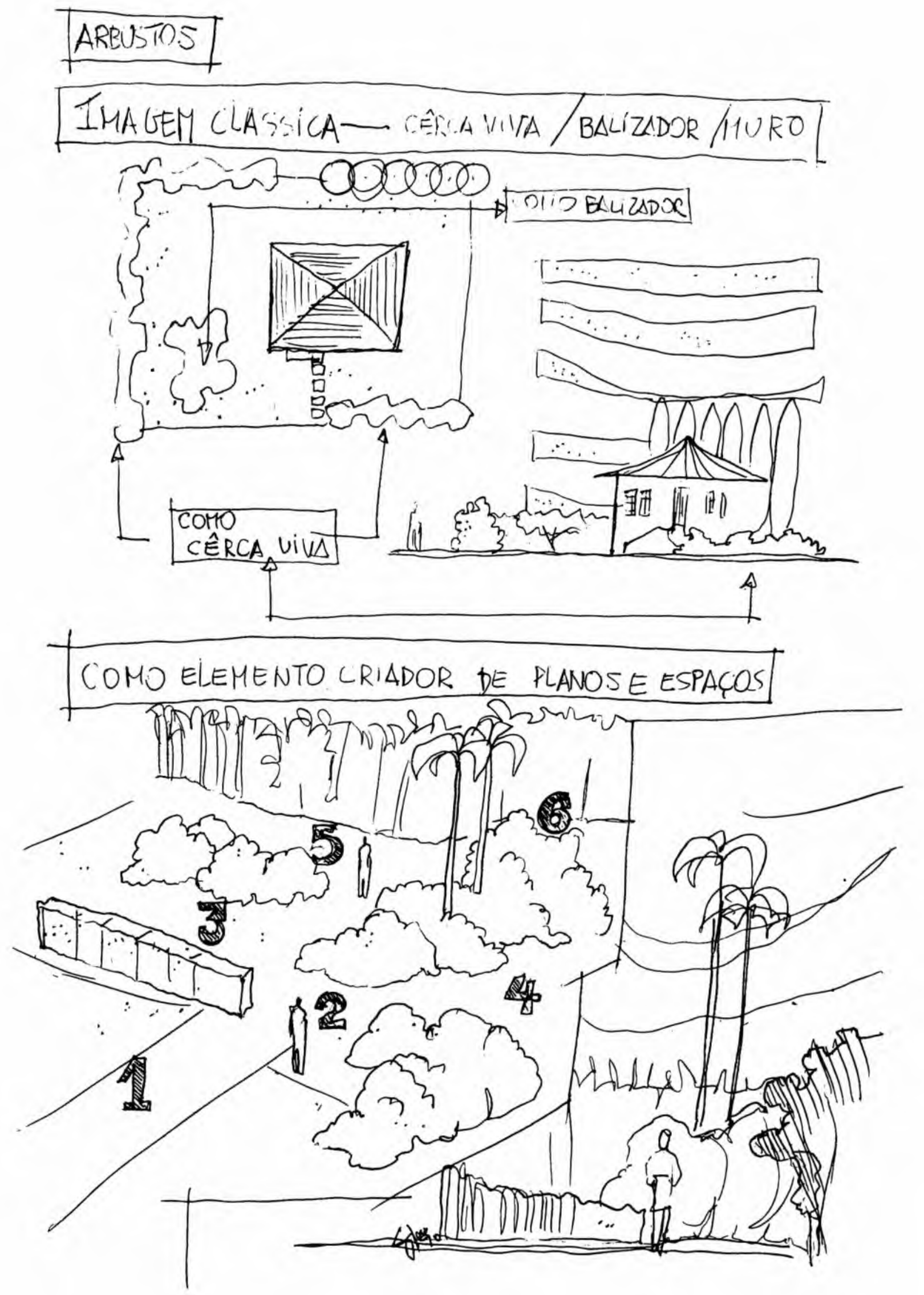




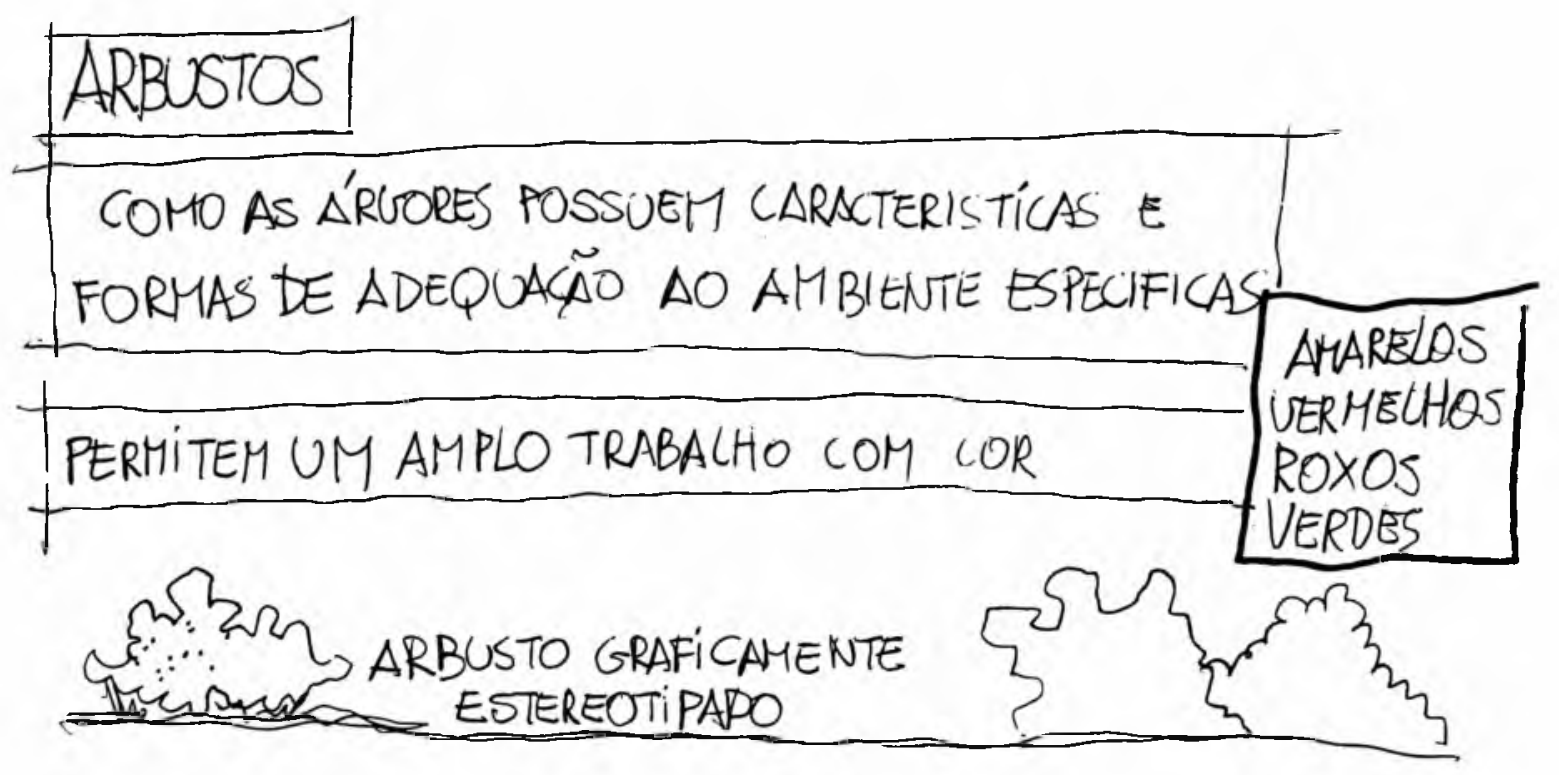

Alguns volumes CLASSI COS
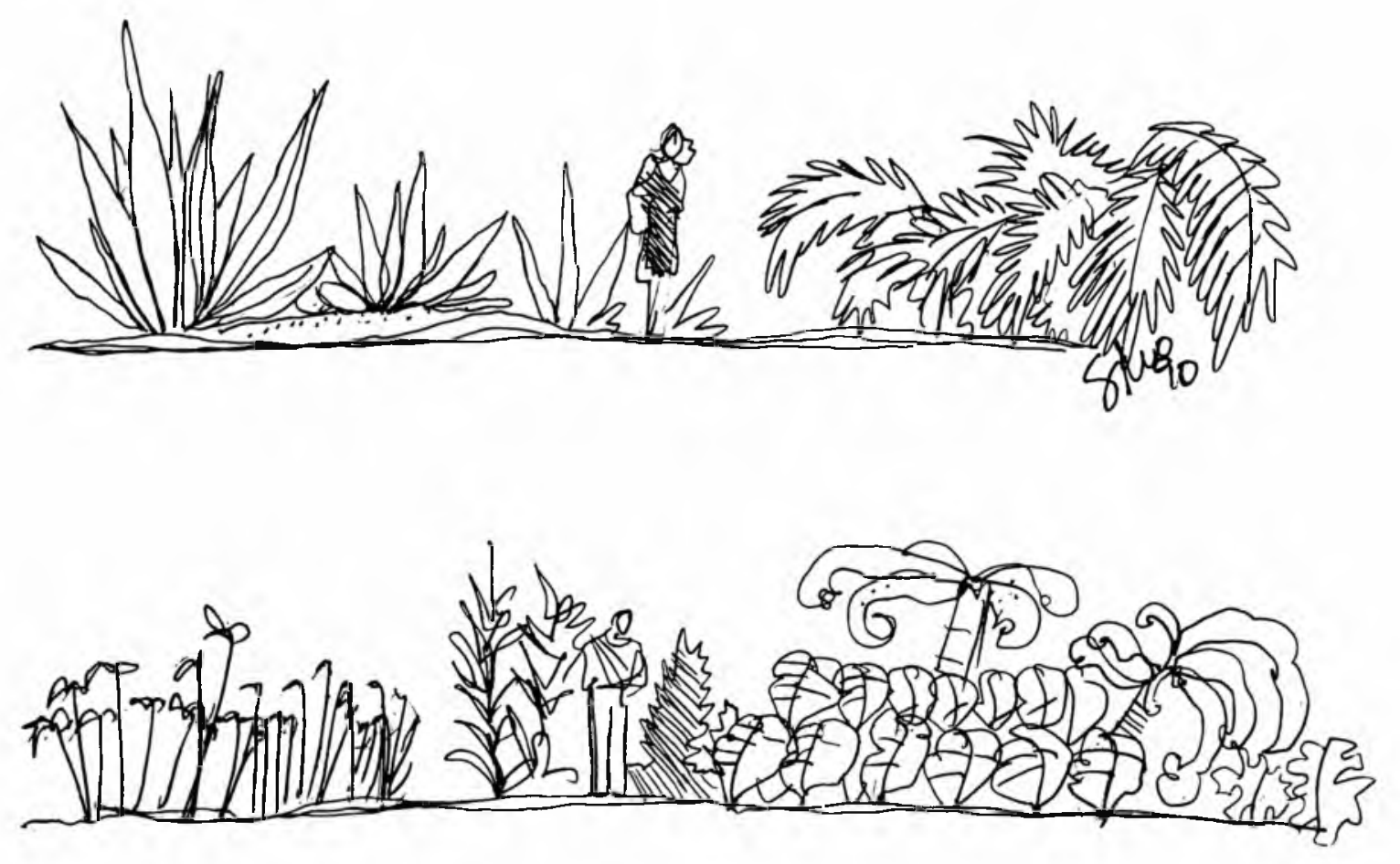
Como elementos de projeto, os arbustos permitem uma diversificada forma de uso e apresentam-se volumetricamente em uma infinidade de formas, tamanhos e cores. Os arbustos mais que as árvores apresentam-se em formas, cores e volumes diferenciados, alguns se assemelhando a pequenas árvores, outros se mostram finos e pontiagudos, verdadeiros elementos escultóricos, outros possuem folhagens de cores diversas e outros se apresentam muito altos, como os bambus, que em alguns casos chegam a ter mais de 5 metros de altura, outros ainda permitem ao homem sua modelagem em várias formas. Este tipo de modelagem é obtido por intermédio de poda constante, e foi uma forma característica de uso dos arbustos e, muitas vezes, das próprias árvores em diversos momentos da história da arquitetura paisagística, encontrando-se exemplos de tal prática dos jardins e parques do renascimento, até no arvoredo dos bairros de elite durante o período do Ecletismo Brasileiro (metade do séc. XIX até os anos 50 ) e até em modernos jardins e praças desenhadas sob a égide do pós-modernismo.

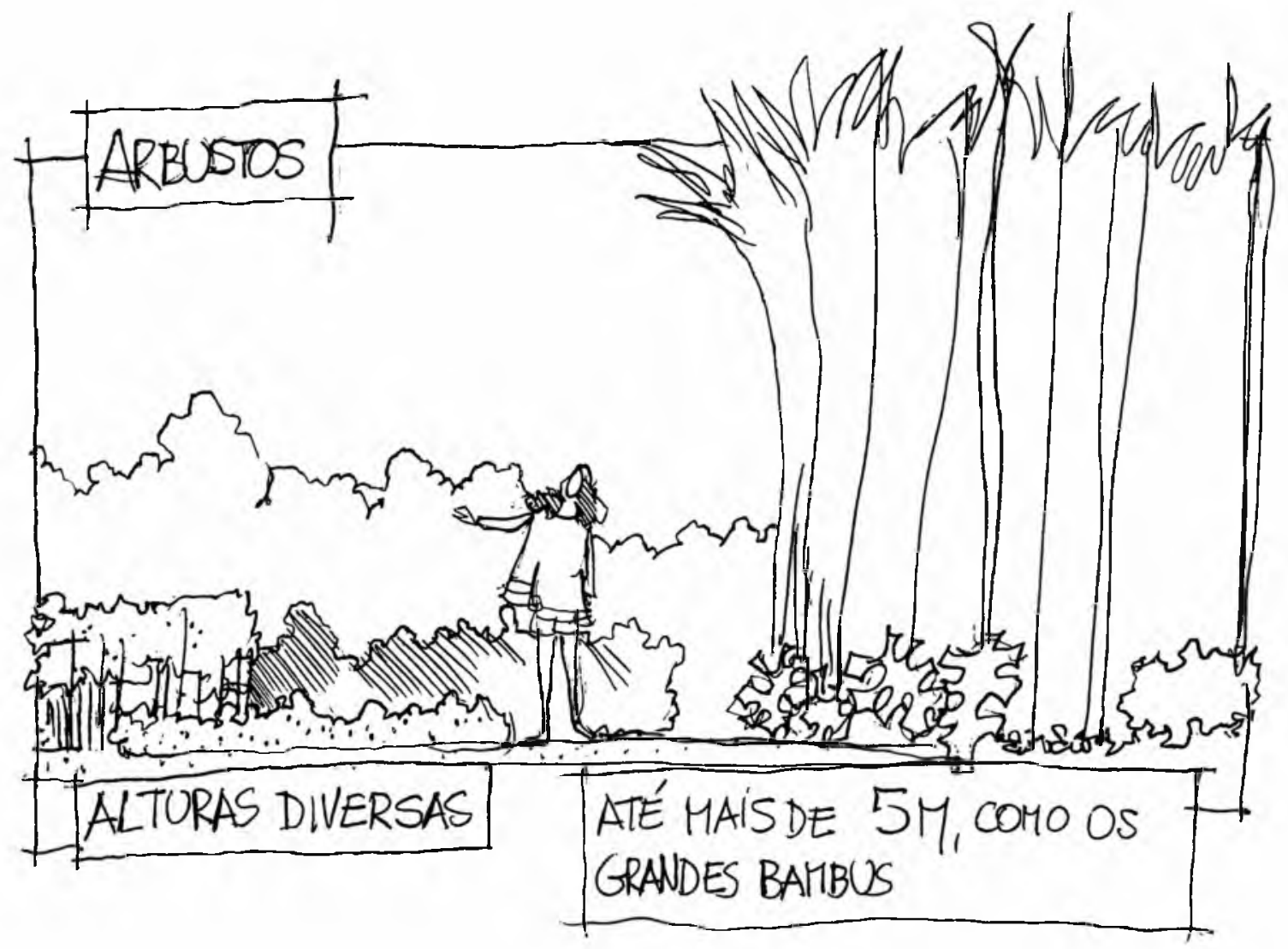



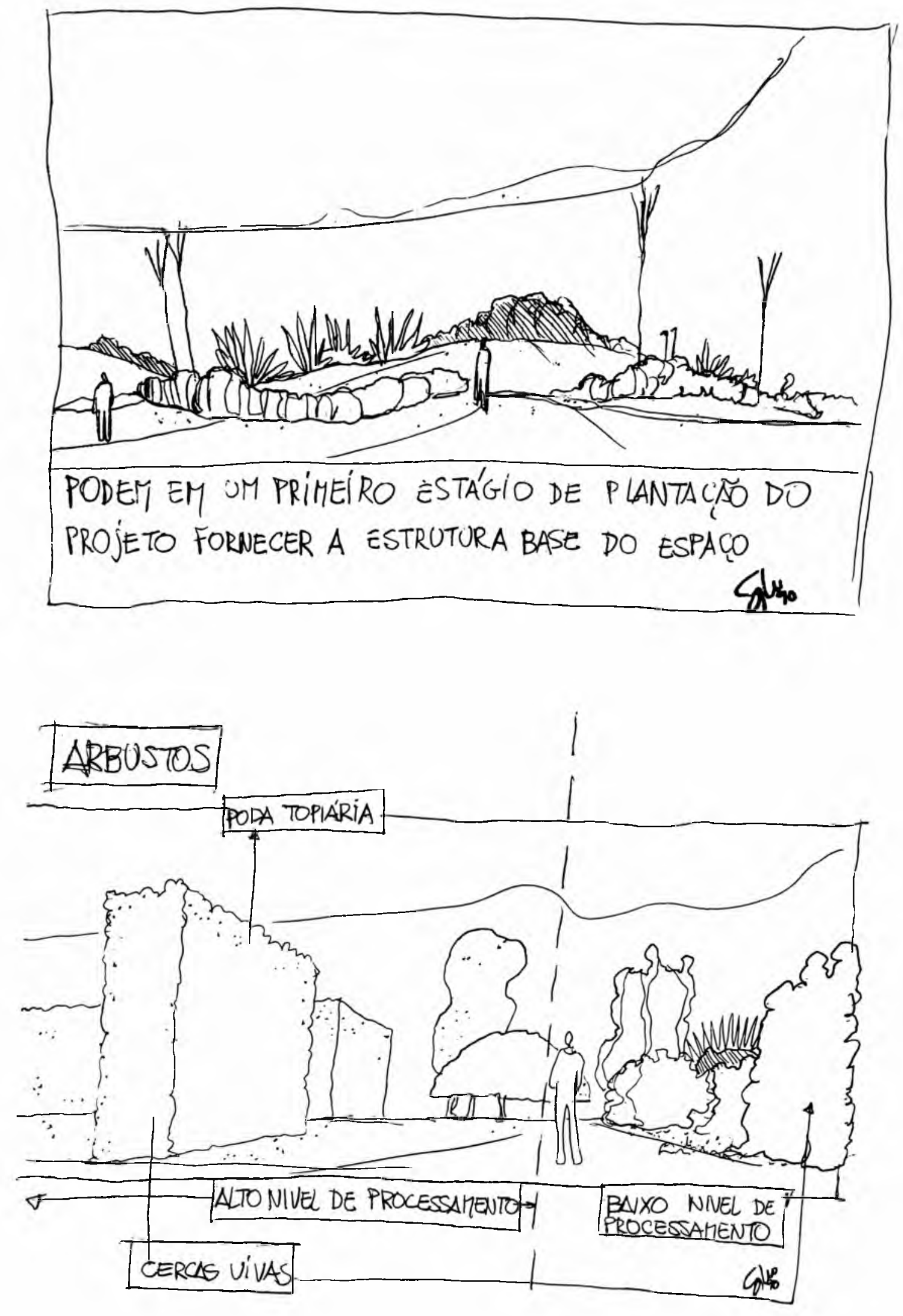


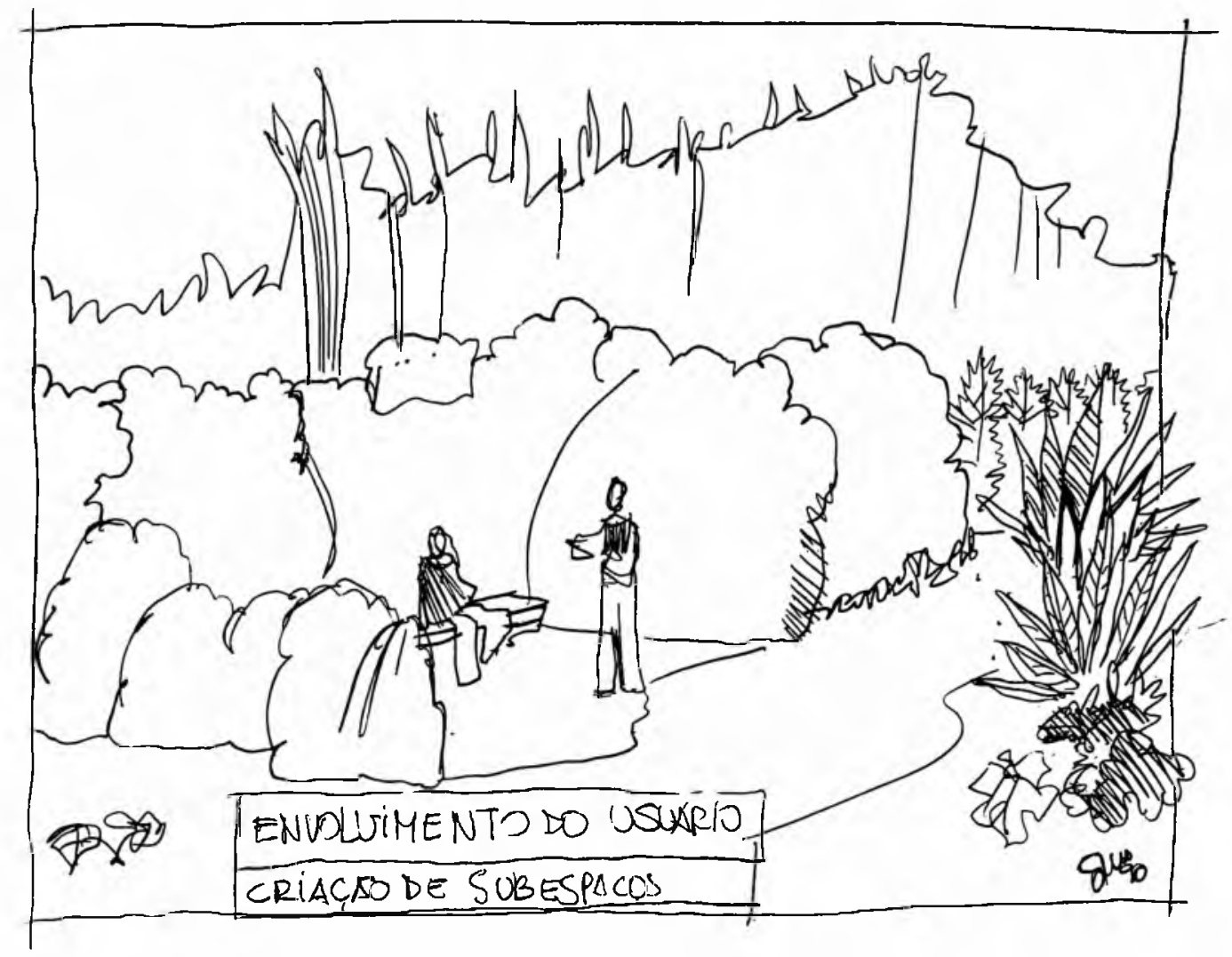

Esta forma de poda denominada topiária é um processo adequado para modelagem de plantas, produzindo muros, cercas, pórticos e esculturas que possuem muitas vezes a forma de "pitorescas" figuras humanas e de animais.

Esta forma de expressão plástica, foi banida dentro de um espírito nacionalista do repertório do paisagismo brasileiro, em detrimento da exploração plástica da luxuriante flora tropical, que apresenta um rápido crescimento, aliado a portes significativos e baixa necessidade de manutenção e cujo uso intensivo caracterizou então a linha projetual do moderno paisagismo nacional.

\section{OS PISOS, AS FORMAÇÕES, GRAMADOS... ETC.}

No projeto de espaços livres urbanos, à exceção de grandes praças e parques ou ainda em algumas propriedades particulares, a utilização da vegetação, no caso as formações é limitada, devido principalmente a dois fatores: a exigüidade do espaço disponível e a dificuldade e alto custo de manutenção.

À exceção dos gramados, todos os outros tipos de forração são muito sensíveis ao pisoteio e estes mesmos, como seres vivos que são, oferecem res- 
trições a um uso contínuo. Este fato pode ser observado claramente nos campos de futebol, onde apesar da alta manutenção apresentada observa-se nas suas áreas de maior uso por jogadores, uma total falta de cobertura de grama, caso do meio de campo e das proximidades das traves de gol. Ainda assim são os gramados de todos os tipos de formação os mais comumente utilizados sejam em áreas públicas ou privadas, de parques a conjunto habitacionais.

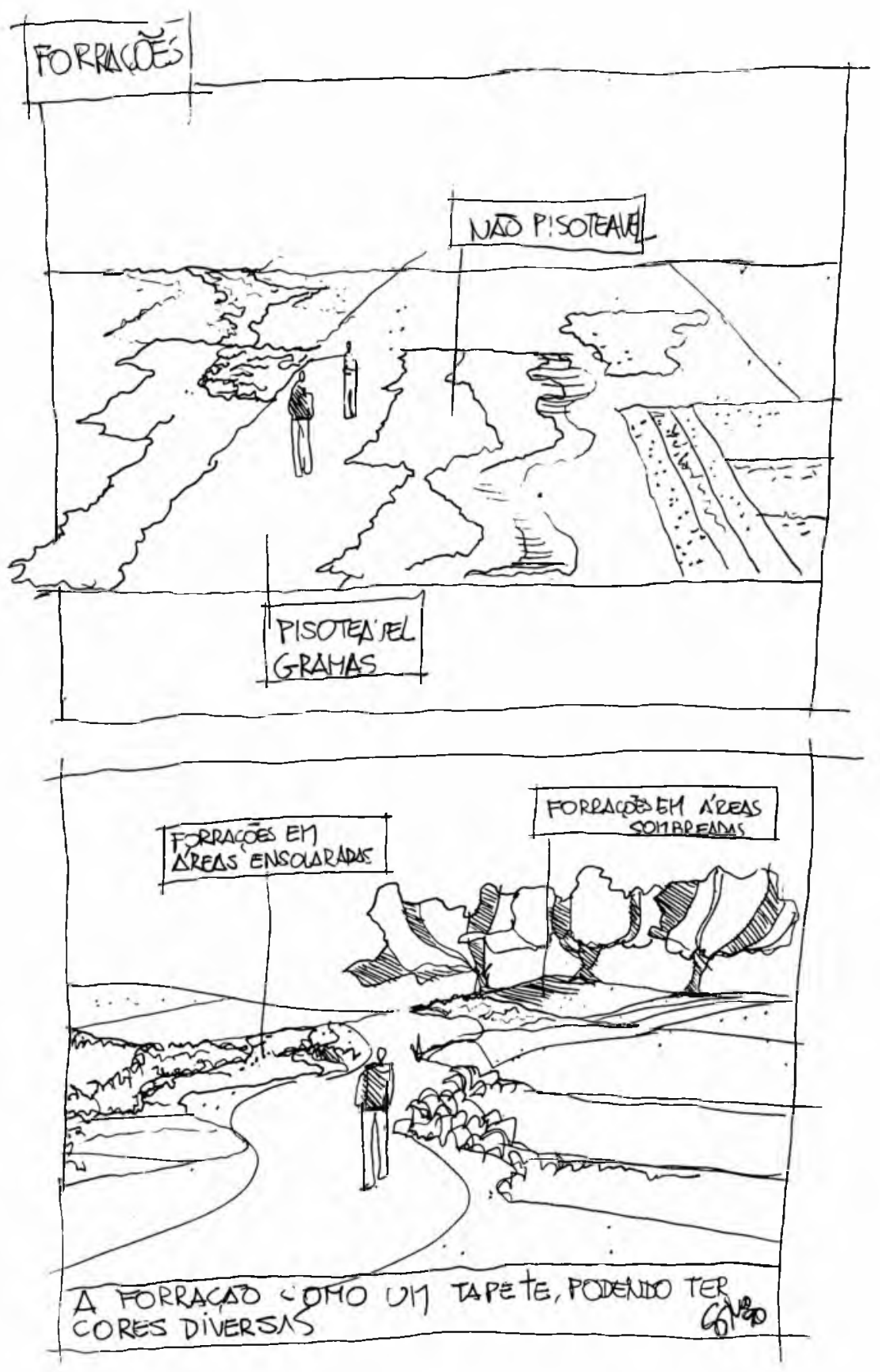


Como no caso dos arbustos, a utilização de forrações tem sido ainda muito pouco explorada, pois à exceção de alguns profissionais de renome, que por um motivo ou outro obtiveram condições ideias de trabalho no tocante a sua utilização, tanto de manutenção como de custos e de disponibilidade espacial para sua colocação. Este é outra vez o caso de Roberto Burle Marx que em alguns de seus melhores projetos explora largamente o potencial das formações como material de construção de pisos - verdadeiros tapetes ricamente desenhados. Como exemplo deve-se notar o Aterro do Flamengo na cidade do Rio de Janeiro, onde utiliza gramados de tons diversos para construir pisos em volta do Museu de Arte Moderna (MAM),balho no tocante a sua utilização, tanto de manutenção como de custos e de disponibilidade espacial para sua colocação. Este é outra vez o caso de Roberto Burle Marx que em alguns de seus melhores projetos explora largamente o potencial das formações como material de construção de pisos - verdadeiros tapetes ricamente desenhados. Como exemplo deve-se notar o Aterro do Flamengo na cidade do Rio de Janeiro, onde utiliza gramados de tons diversos para construir pisos em volta do Museu de Arte Moderna (MAM), ou parques particulares de Odete Monteiro e Nininha Magalhães, onde explora a variação de cores na busca de elementos diversos para a composição de um cenário requintado.

No dia a dia projetual, mesmo no caso de parques públicos, o uso dos grandes gramados predominam, pois tem sido o material mais indicado devido ao fato das vantagens, já referidas, de manutenção e resistência, perdendo-se de fato e portanto contigências reais as condições excepcionais de exploração das forrações como material de projeto. Como os arbustos, as forrações oferecem posssibilidades múltiplas de uso, de acordo com os graus de processamento que se deseja implementar, dos pisos mais processados aos mais rústicos e podendo ser aplicadas tanto em áreas de sombra ou de sol, de acordo com a espécie e a linha projetual adotada.

\section{BIBLIOGRAFIA}

ABBUD, Benedito. Vegetação e Projeto: estudo de caso em São Paulo com as reflexōes de um arquiteto. São Paulo, 1986. Diss. (Mestr.) - FAUUSP.

BARDI, Pietro M. The Tropical Gardens of Burle Marx. Colibri Editora Ltda., 1964.

CARDOSO, Omar de Almeida. Relatório final de Pesquisa CNPq Bolsa de Iniciação Científica. "Arquitetura Paisagística e a Cidade, do Ecletismo ao Moderno: Fundamentos Conceituais e Rebatimentos Espaciais". FAUUSP, 1991. 
CASTILHA, Marcos. Relatório Final de Pesquisa CNPq - Bolsa de Iniciação Cientifica "Arquitetura Paisagística e a Cidade, do Eclestimo ao Moderno: Fundamentos Conceituais e Rebatimentos Espaciais". FAUUSP, 1991.

DIEBERGER, R. \& Cia. Arte e Jardim. São Paulo, s. ed. 1928.

GUARALDO, Eliane. Relatório Final de Pesquisa CNPq - Bolsa de Aperfeiçoamento. "Arquitetura Paisagística e a Cidade, do Ecletismo ao Moderno: Fundamentos Conceituais e Rebatimentos Espaciais". FAUUSP, 1991.

HACKETT, Brian. Planting Design. New York, McGraw Hill, 1979.

LAURIE, M. An Introduction to Landscape Architecture. London, Pitman Publishing Ltd., 1978.

MACEDO, Silvio Soares. O Bairro de Higienópolis e Arredores. São Paulo, Pini, 1987.

. São Paulo, Paisagem e Habitação Verticalizada, Os Espaços Livres como Elementos de Desenho Urbano. São Paulo, 1988. Tese (Dout.), FAUUSP.

MOTTA, Flávio L. Roberto Burle Marx e a Nova Visāo da Paisagem. São Paulo, Nobel, 1984.

REIS, Jose de Oliveira. História Urbanística do Rio de Janeiro/ O Rio: Cidade dos pântanos e lagoas. In: Revista Municipal de Engenharia. Prefeitura Municipal do Rio de Janeiro, v. XL, 1988, p. 3-86.

REIS, Nestor G. Quadro da Arquitetura no Brasil. São Paulo, Perspectiva, 1970.

TOBEY JR., George B. A History of Landscape Architecture: The Relationship of People to Environment. New York, Elsevier, 1973.

TOLEDO, Benedito Lima. Álbum Iconográfico da Avenida Paulista. São Paulo, Exilibris, 1987. 